1978

\title{
Investigation of Prehistoric Rockshelter and Terrace Sites Along Portions of the Salado Creek Drainage, Nothern Bexar County,
}

\section{Texas}

\author{
A. Joachim McGraw \\ Fred Valdez Jr. \\ Department of Anthropology, The University of Texas at Austin
}

Follow this and additional works at: https://scholarworks.sfasu.edu/ita

Part of the American Material Culture Commons, Archaeological Anthropology Commons, Environmental Studies Commons, Other American Studies Commons, Other Arts and Humanities Commons, Other History of Art, Architecture, and Archaeology Commons, and the United States History Commons

Tell us how this article helped you.

This Article is brought to you for free and open access by the Center for Regional Heritage Research at SFA ScholarWorks. It has been accepted for inclusion in Index of Texas Archaeology: Open Access Gray Literature from the Lone Star State by an authorized editor of SFA ScholarWorks. For more information, please contact cdsscholarworks@sfasu.edu. 
Investigation of Prehistoric Rockshelter and Terrace Sites Along Portions of the Salado Creek Drainage, Nothern Bexar County, Texas

\section{Creative Commons License}

(c) (i) (8)

This work is licensed under a Creative Commons Attribution-NonCommercial 4.0 International License 


\section{INVESTIGATION OF PREHISTORIC ROCKSHELTER ADD TERRRCE SITES ALONG PORTIOOSS OF THE SALLDO CREEK DRAIIRGE, nORTHERก BEXAR COUNTY, TEXAS}

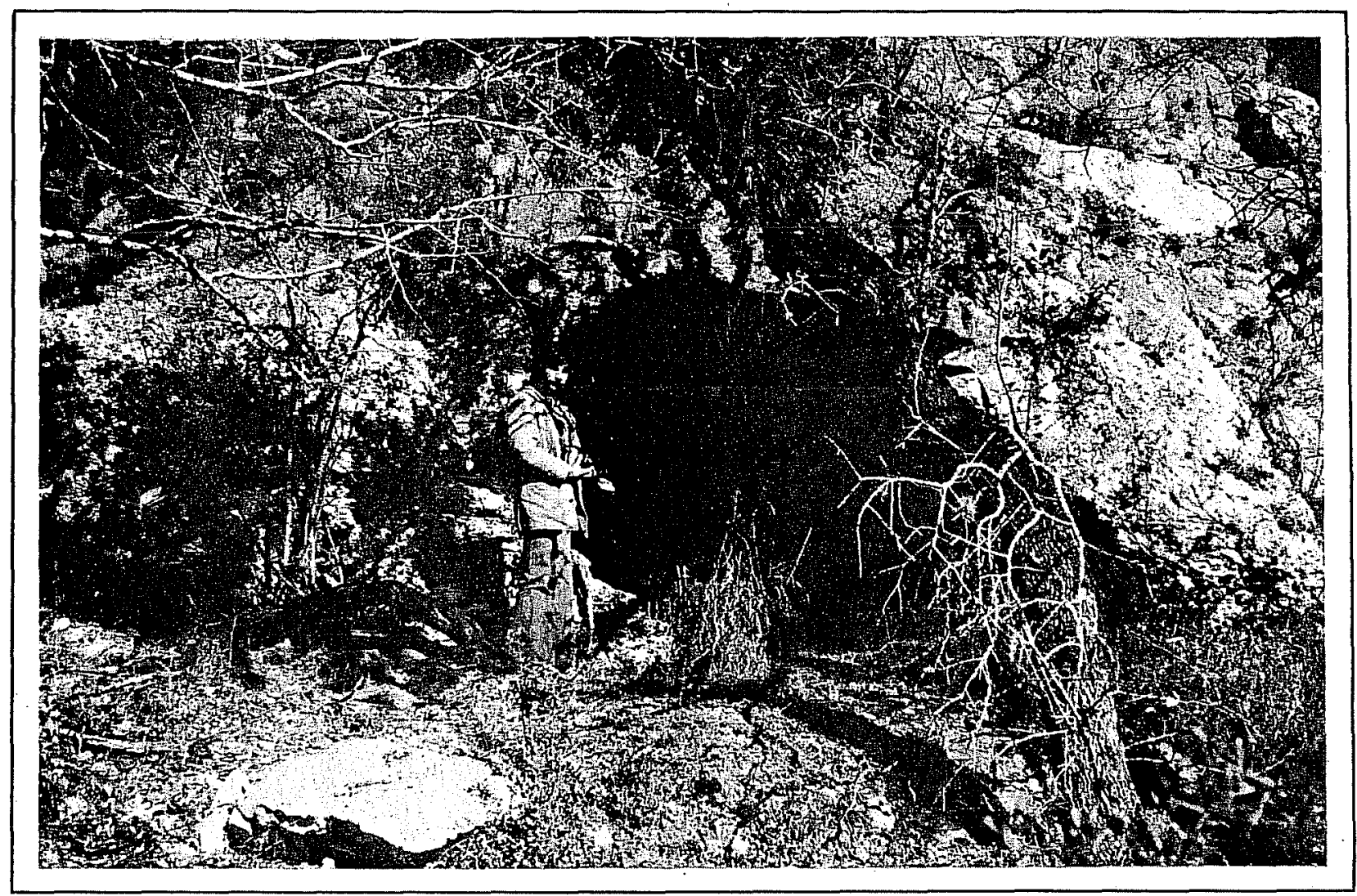

A. Joachim McGraw and Fred Valdez, Jr.

Center for Archaeological Research The University of Texas at San Antonio Archaeological Survey Report, No. 55 


\section{INVESTIGATIONS OF PREHISTORIC ROCKSHELTER AND TERRACE SITES ALONG PORTIONS OF THE SALADO CREEK DRAINAGE, NORTHERN BEXAR COUNTY, TEXAS}

A. Joachim McGraw and Fred Valdez, Jr.

Center for Archaeological Research The University of Texas at San Antonio Archaeological Survey Report, No. 55

1978

Photocopy Reprint 
This report is submitted in fulfillment of a contract between the Center for Archaeological Research, The University of Texas at San Antonio and the Soil Conservation Service, United States Department of Agriculture, Purchase Order 40-7442-7-1601, dated September 15, 1977. 


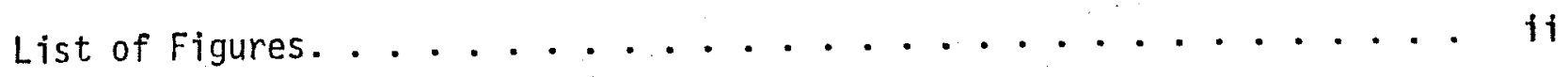

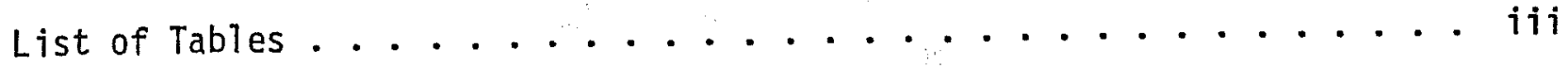

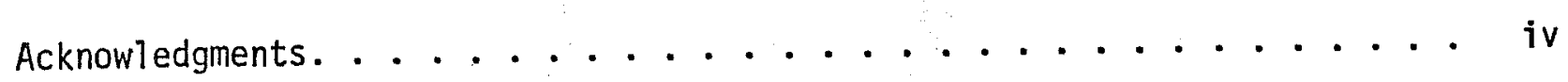

Introduction . . . . . . . . . . . . . . . . . 1

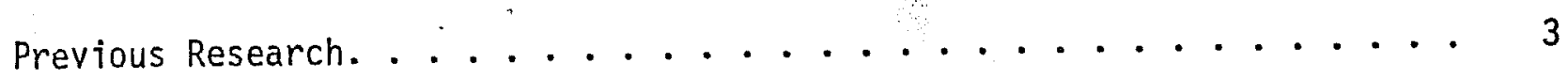

Chronology of Prehistoric Habitation ................ 3

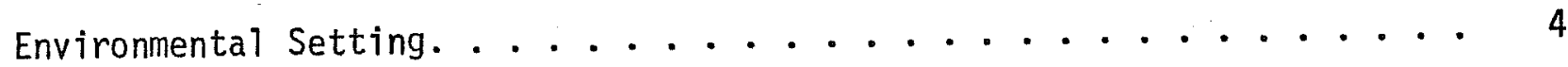

The Sites........................... 8

Floodwater Retarding Structure 3............. 8

Floodwater Retarding Structure 6.................... 14

Floodwater Retarding Structure $10 \ldots . . \ldots 21$

Floodwater Retarding Structure $15 \ldots . . \ldots 28$

Lithic Analysis. . . . . . . . . . . . . . . 31

Cores and Lithic Debris . . . . . . . . . . . . 31

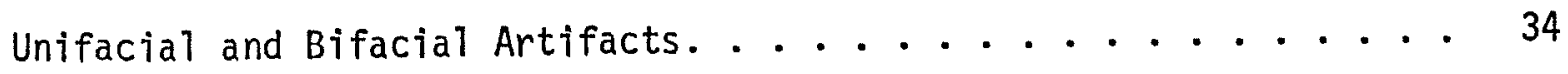

Summary and Recommendations. . . . . . . . . . . . 35

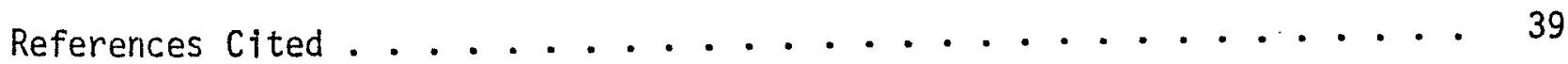




\section{LIST OF FIGURES}

Figure

Page

1. Map Showing the Locations of Floodwater Retarding Structures

$3,6,10$ and $15 \ldots . . . . . . . . . .2$

2. Map of Tested Sites at Floodwater Retarding Structure $3 \ldots$. . 9

3. Map of Test Units at Site 3-1 (41 BX 442) ......... 10

4. Map of Test Units at Site 3-3 (41 BX 444) . . . . . . . 12

5. Map of Sites at Floodwater Retarding Structure 6. . . . . 15

6. Rocksheiter 6-1A (41 BX 362). . . . . . . . . 16

7. Profile of North Wall of TP-1, Rockshelter 6-1A (41 BX 362) . . 18

8. Profile of South Wall Section of Trench B, Rockshelter 6-1A (41 BX 362)............ 19

9. Rockshelter 6-1B (41 BX 362)............ 20

10. Map of Test Units at Site $6-2(41 \mathrm{BX} 363) \ldots 22$

11. Map of Archaeological Sites at Floodwater Retarding Structure 10 (41 BX 452). . . . . . . . . . 23

12. Rockshelter Complex 10-3A (4r BX 452) ......... 25

13. Map of Test Units at Rockshelter A-3, Complex 10-3A (41 BX 452) .............. 26

14. View of Rockshelter B-2, Complex 10-3B, Looking North . . . . 27

15. Map of Floodwater Retarding Structure 15 and Archaeological Site 15-3 (41 BX 173). ......... 29

16. Site 15-3 (41 BX 173) ............... 30

17. Artifacts from Floodwater Retarding Structures 3 and $6 . . .32$

18. Artifacts from Floodwater Retarding Structures 6, 10 and 15 . . 33 


\section{LIST OF TABLES}

Table

Page

1. Some Past and Present Flora of Bexar County . . . . . . 6

2. Some Past and Present Fauna of Bexar County ... . . . . 7

3. Provenience of Lithic Materials ........... 13

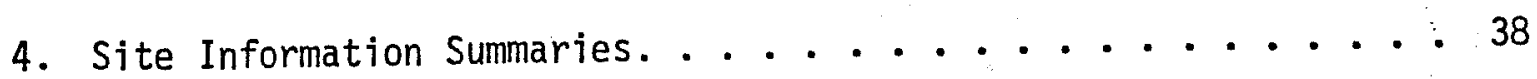




\section{ACKNOWLEDGMENTS}

The writers of this report are indebted to all those whose cooperation made this report possible. Special thanks is extended to Mr. R. Sandy of the Canyon Creek Country Club for his friendly cooperation and to Mr. Jim Thompson of the San Antonio River Authority. Volunteer workers Kathy Gonzalez, Sampale Lindholm and Rebekah Halpern contributed greatly to the timely and professional accomplishment of the field work. The project was carried out under the general supervision of Dr. Thomas R. Hester (Director, Center for Archaeological Research. The University of Texas at San Antonio) and Mr. Jack D. Eaton (Assistant Director). 


\section{INTRODUCTION}

During late fall and winter of 1977, personnel from the Center for Archaeological Research, The University of Texas at San Antonio. (UTSA), conducted 1imited test excavations and controlled surface collections along portions of the Salado Creek drainage in northern Bexar County (Fig. 1). Four specific areas were examined, as they were soon to be inundated or critically altered by proposed floodwater retarding structures. The sites in these locations had previously been identified and recommended for further work by Hester et al. (1974). During field operations, the areas of Floodwater Retarding Structures 3, 6, 10 and 15 were investigated. A total of four terrace sites, two small rockshelters and two rockshelter complexes were tested. Of the shelters, one complex and one individual shelter, both previously unrecorded, were discovered in the immediate vicinity of the retarding structures during the course of testing operations. Testing was concentrated in the immediate vicinities of Mud Creek, Panther Springs Creek and portions of the main channel of Salado Creek.

Methodology involved throughout the testing period was based upon a systematic examination following the guidelines presented in Field Methods in Archacology (Hester, Heizer and Graham 1975). The current study of the dam site areas was directed toward: (1) a preliminary assessment of the archaeological sites in terms of their content and importance; (2) the detailed recording of such information for further research; and (3) recommendations for any further investigations at the sites. Observations of material distributions were noted not only to define site boundaries but also to distinguish areas of particular site activity. Consideration was also given to the presence or absence of particular cultural materials as well as to horizontal and vertical distances from water sources. Except at dam site 15, controlled surface collection was rejected as inefficient in terms of both time and manpower.

A11 information has been recorded on standard excavation forms presently used by the Center for Archaeological Research, The University of Texas at San Antonio. Black and white $35 \mathrm{~mm}$ photographs and color slides were also taken of various sites and features. Artifacts collected were placed in plastic or paper bags and labeled as to tested area, level of excavation, date, type of collection and collector's name. All materials were collected and processed according to standard archaeological procedures, and the assessments presented in this study are based upon a preliminary examination of the recovered artifacts, photographs, excavation forms and field notes.

The project was conducted under contract between the Center for Archaeological Research, The University of Texas at San Antonio and the Soll Conservation Service, United States Department of Agriculture. All field work was done under the supervision of Dr. Thomas R. Hester, Director, and Mr. Jack D. Eaton, Assistant Director, Center for Archaeological Research. The field crew consisted of A. Joachim McGraw, Fred Valdez, Jr., Santiago Escobedo and Curtis McKinney, assisted by volunteers Rebekah Halpern, Kathy Gonzalez and Sampale Lindholm. 
This page has been

redacted because it

contains restricted

information. 


\section{PREVIOUS RESEARCH}

The sites discovered during the course of the preliminary survey of Salado Creek in 1974 (Hester et al.), like many other sites identified in Bexar County in the last five years, are the direct result of an intensive program of contract archaeology by the Center for Archaeological Research, UTSA. The cumulative result of these efforts has been the identification and recording of over 450 archaeological sites in Bexar County, thereby making it one of the most archaeologicaliy studied counties of Texas. Much of this work, however, is at a preliminary survey level with limited sustained research.

Salado Creek and its tributaries have been a major focus of expanding study in northern Bexar County. Brief discussions of its prehistoric significance are mentioned by Fawcett (1972), although his approach was that of area interrelationships rather than site specificity. Recent investigations by Hester et al. (1974), Smith and McDonald (1975), Brown et al. (1977), Fox (1977), McGraw, Valdez and Cox (1977), Jaquier et al. (1978), McGraw and Valdez (1977) and Gerstle, Kelly and Assad (1978) have shed new light on the complex archaeological patterns of the ancient drainage.

Sites of major archaeological significance in northern Bexar County along the Salado Creek drainage include 41 BX 22, the Rogers site; 41 BX 228, Walker Ranch; $41 \mathrm{BX} 300$, the Elm Waterhole Creek site; $41 \mathrm{BX} 229$, the St. Mary's Hall site; $41 \mathrm{BX} 17$, the Granberg site (Schuetz 1966); and $41 \mathrm{BX} 271$, the Granberg II site. These sites contain a variety of artifacts from the Paleo-Indian through the Historic Indian periods of south central Texas.

\section{CHRONOLOGY OF PREHISTORIC HABITATION}

Although current research has made major inroads into the complexities of the long-forgotten aboriginal cultures of south central Texas, the archaeology of the transition zone between the lower Gulf Coastal Plain and the Edwards Plateau region is still poorly defined. Refined archaeological techniques have broadened the horizon of prehistoric studies; in many cases, however, even the most current analyses are limited by the lack of a distinctive chronology and by an often inconsistent typological system of diagnostic artifact classification. Generally, four major time periods of aboriginal activities are reflected in sites within the immediate vicinity of the dam site study areas. These major time periods are briefly defined as the Paleo-Indian, the Archaic, the Late Prehistoric (or Neo-American) and the Historic. Temporally distinct, these periods are characterized by particular 11 thic industries, distinctive projectile point styles and a variety of other criteria presumably based on subsistence patterns and general adaptations to changing environmental and/or cultural conditions.

The earliest of these periods, the Paleo-Indian (ca. 9200-6000 B.C.), is represented in the vicinity of the study area at 41 BX 229, the St. Mary's Hall site, along the main channel of Salado Creek and within the city limits of San Antonio. Preliminary analyses suggest an extensive Paleo-Indian campsite reflected by Folsom, Plainview, Golondrina and Angostura projectile points (Hester 1978). 
While it has been assumed the Archaic period (ca. 6000 B.C.-A.D. 1000) generally follows the Paleo-Indian period, there is increasing evidence in central and south Texas of a transitional phase following the Paleo-Indian period and preceding the presently defined "Early Archaic." Tentatively labeled the "Pre-Archaic," a series of sites, including Baker Cave, Stillhouse Hollow, La Jita and others, suggests major lithic characteristics from this period include large barbed points, notched and triangular dart points, and stemmed points termed Gower (Hester 1975).

The second major time period, the Archaic, covers a long temporal span. Diagnostic lithic materials throughout much of North America suggest a common subsistence pattern of seasonal migrations and hunting and gathering lifeways. Due to enviro-climatic changes at the end of the Pleistocene, emphasis on hunting shifted away from the "big game" animals of the Paleo-Indian period to smaller animals such as deer and modern species of bison. Commonly divided into Early, Middle and Late subperiods, the Archaic occupations throughout Texas are represented by an abundance of chipped stone artifacts, a wide variety of dart point types, 11 thic forms such as Clear Fork and Guadalupe tools, and large thin bifaces. The highest frequency of datable sites near the study area is linked to Middle and Late Archaic occupations (Hester et al. 1974; Soliberger and Hester 1972).

A significant cultural change in south central Texas occurs after A.D. 1000 with the beginning of the Late Prehistoric (Neo-American) period. The introduction of ceramics and the bow and arrow abruptly modified archaeological assemblages. Small arrow points of distinctive types, new lithic forms and bone-tempered ceramics made their appearance during these times.

The fourth period, the Historic, is represented during and after early European contacts by intrusive Plains Indians, such as the Lipan Apache and Comanche. They moved into the area in the 17th and 18th centuries after Spanish "missionization" and cultural breakdown of native groups.

The variety of archaeological sites found in northern Bexar County along the Salado Creek drainage includes occupation sites (campsites), burned rock middens, chert quarries and workshops, temporary campsites and rockshelters. (For additional descriptions of Bexar County sites, see Fawcett 1972.)

\section{ENVIRONMENTAL SETTING}

This report will present only a cursory review of the more important environmental factors affecting the past and present conditions of the study areas. The reader is referred to Scurlock and Hudson (1973), Fawcett (1972), Hudson, Lynn and Scurlock (1974), McGraw, Valdez and Cox (1977) and Gerstle, Kelly and Assad (1978) for more detailed discussions.

Bexar County is located in the transition zone between the southern limits of the Edwards Plateau Escarpment and the lower Gulf Coastal Plain. It is bounded on the north by Kenda11, Comal and Guadalupe Counties, on the west by Bandera and Medina Counties, on the east by Wilson County, and on the south by 
Atascosa County. Major drainages, all of which flow southward across the area, include the Medina and San Antonio Rivers. Secondary tributaries include the Salado, Leon and Calaveras Creeks, along with their numerous tertiary systems. The Medina River later joins the San Antonio River in the southeastern margins of the county.

Physiographically, the northern limits of the county are on, or adjacent to, the recharge zone of the Edwards Aquifer; local topography is reflective of the Texas Hill Country, characterized by prominent eroding limestone elevations and light, calcareous soil cover. Permanent water sources are few, but springs and intermittent drainage systems are interspersed throughout the region.

Elevations in northern Bexar County vary from ca. 1250 feet above mean sea level on hilltops to below 700 feet along drainage channels. Fawcett (1972) suggests two other physiographically distinct regions for the county: a transition zone just south of the Edwards Plateau and a southern zone located in the sandy soils of the Guif Coastal Plain. The archaeological sites of the study area are located in the general northern transition zone. Elevations in the study area vary from 950 feet above ms 1 in upland areas to ca. 870 feet along stream beds. Soils in the immediate vicinities generally consist of three distinct associations, although this does not reflect complexities caused by the local drainages in the forms of redepositions, erosion, alluviums, etc. Major soil associations include: Crawford-Bexar soils, moderately deep, stony soils over limestone; Tarrant-Brackett soils, shallow and very shallow soils over limestone; and Lewisville-Houston Black, terrace-associated, deep calcareous soils in oil alluvium (Taylor, Hailey and Richmond 1966).

\section{Climate}

The climate in Bexar County can be described as modified subtropical: mild in the winter and hot in the summer. Record high and low temperatures vary from $106^{0}$ to $0^{0}$, while daily maximum and minimum averages are $79.2^{\circ}$ and $58.1^{0}$ (Taylor, Hailey and Richmond 1966). Precipitation is usually evenly distributed throughout the year, averaging 27.84 inches per year. Rain in the form of thunderstorms falls in all seasons except winter and often results in flooding of local waterways and low water areas (McGraw, Valdez and Cox 1977). North winds predominate during the winter and southeasterly Gulf winds predominate during the summer. The relative humidity normally ranges from $80 \%$ in the morning to ca. $50 \%$ by late afternoon. The period from the last spring freeze to the first freeze in fall averages 245 days (Taylor, Hailey and Richmond 1966).

Flora and Fauna

Salado Creek and its tributaries, within the study area, fall within the general transition zone of the Balconian and the Tamaulipan Biotic Provinces as described by Blair (1950). A discussion of the flora and fauna is beyond the scope of this report, although a detajled list of flora and fauna in the vicinity of the study area is presented in Tables 1 and 2 (Gerstle, Kelly and Assad 1978). 
TABLE 1. SOME PAST AND PRESENT FLORA OF BEXAR COUNTY Adapted from Gerstle, Kelly and Assad (1978)

\author{
Juniper (Juniperus ashei) \\ Texas oak (Quercus texana) \\ Live oak (Quercus virginiana) \\ Pecan (Carya illinoinensis) \\ Cedar elm (U emus crassifolia) \\ Cottonwood (Populus deltoides) \\ Hackberry (Celtis reticulata) \\ Mesquite (Prospopis sp.) \\ Texas persimmon (Diospyros texana) \\ Red buckeye (Aesculus pavia) \\ Mountain Taurel (Sophora secundiflara) \\ Texas red bud (Cercis texensis) \\ Whitebrush (Aloysia Rigustrina) \\ Huisache (Acacia farmesiana) \\ Catclaw (Acacia sp.) \\ Agarita (Berberis trifoliolata) \\ Sumac (Shus sp.) \\ Poison ivy (Rubus tocicodendrum) \\ Blackberry (Rubus triviolis) \\ Mustang grape (Vitis mustangensis) \\ Sunflower (Helianthus annuris) \\ Wild verbena (Verbena bifinnatifida) \\ Twisted-leaf yucca (yucca rubicoia) \\ Spanish dagger (Yucca treculeana) \\ Arkansas yucca (yucca arkansana) \\ Sotol (Dasylirion texensis) \\ Prickly pear (Opuntia lindheimeri) \\ Tasajilio (Opuntia leptocaulis) \\ Buffalo grass (Buchloe dactyloides) \\ Beargrass (Nolina texana)
}


TABLE 2. SOME PAST AND PRESENT FAUNA OF BEXAR COUNTY Adapted from Gerstle, Kelly and Assad (1978)

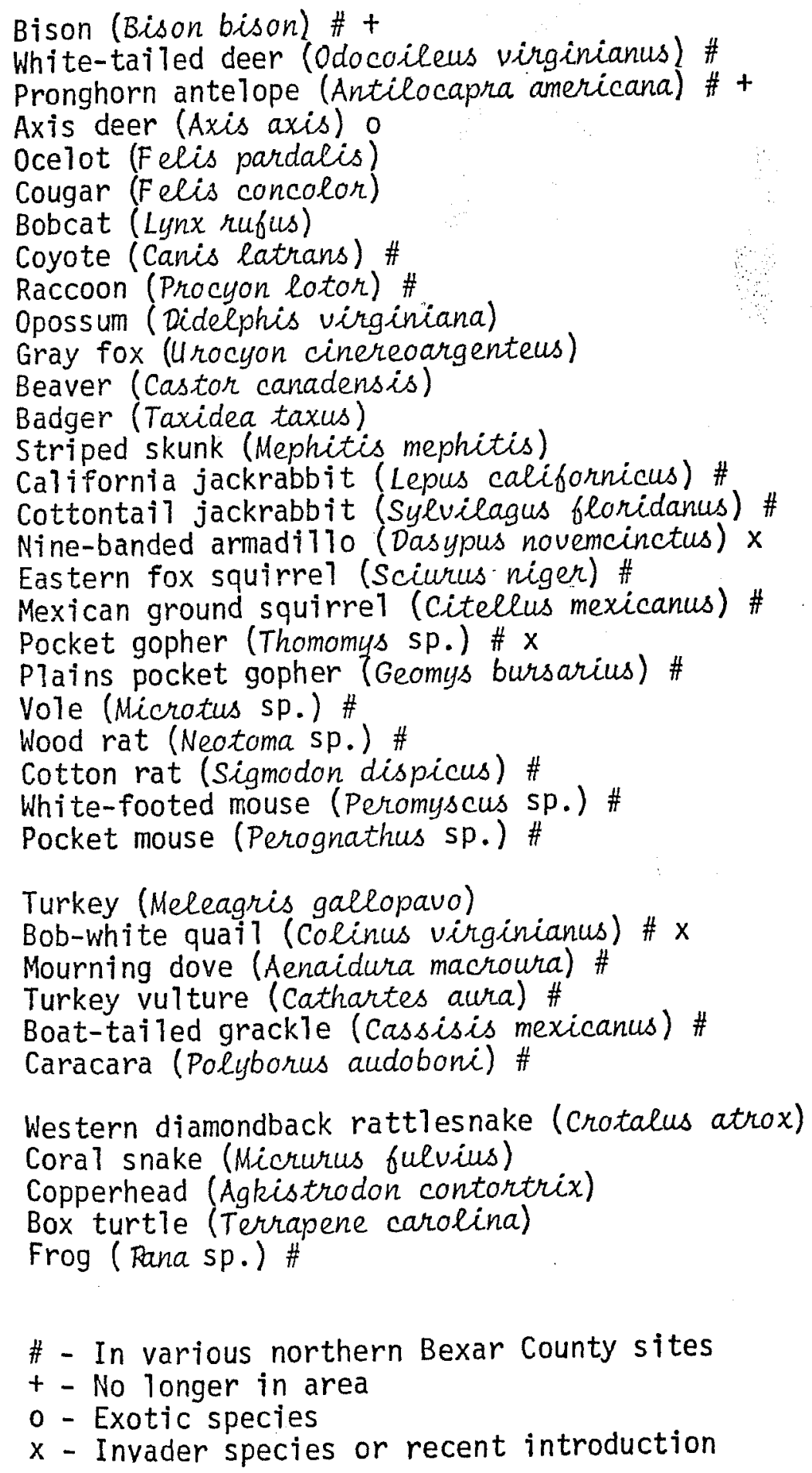


Those readers interested in a more detailed account of the geology, soils, vegetation and faunal patterns in the area are referred to BTair (1950), Fawcett (1972), Scurlock and Hudson (1973), Taylor, Hailey and Richmond (1966), Carr (1969) and McGraw, Valdez and Cox (1977).

\section{THE SITES}

Floodwater Retarding Structure 3

The examination of Floodwater Retarding Structure 3 was concerned with the subsurface testing of two sites previously located in the proposed dam site area: the terrace site of 3-1 (41 BX 442) and the sma11, burned rock midden site of 3-3 (41 BX 444). The dam site area is located on the main channel of Salado Creek north of FM 1604 and about 1.6 miles west of the intersection with Military Highway. The horseshoe bend of the creek on which both sites are located is adjacent to a steep cliff that towers 50 to $60 \mathrm{~m}$ above the eastern bank of Salado Creek. The area is densely overgrown with Juniperus ashei and visibility in many areas is less than $15 \mathrm{~m}$ (Fig. 2).

\section{Site 3-1 (41 BX 442)}

The archaeological site of 3-1 had previous Ty been identified as a limited Tithic scatter, routhly $60 \times 45 \mathrm{~m}$ in area, along a low stream terrace west of the horseshoe bend. After an intensive surface survey, the field team conducting the present test operation has concluded the 1ithic scatter extends 200 to $300 \mathrm{~m}$ west (away) from the bank of Salado Creek and northward (upstream) for about $300 \mathrm{~m}$ toward the archaeological site of 3-2 (41 BX 443). The intensive survey could not distinguish the boundaries of either site in the latter area, although specific concentrations of lithic materials were continuously noted. Present conclusions tentatively suggest the entire fossil flood plain and accompanying terraces throughout this region of the stream valley were extensively occupied in prehistoric times, and the archaeological sites of 3-1 and 3-3 are, for practical purposes, only a sma71, indistinguishable portion of the total extent of prehistoric activity in this locality. Because of the large area involved in this conception, it was decided to test only specific areas, as outlined in the preliminary report, which would be altered or destroyed by the construction of Floodwater Retarding Structure 3.

The low terrace originally defined as 3-1 was tested for a length of over $200 \mathrm{~m}$ along a north-south axis by a series of $50-\mathrm{cm}^{2}$ shovel tests spaced at $30-\mathrm{m}$ intervals. To gain a better understanding of the extent of activity away from the creek bank and westward toward the upland slopes, four more $50-\mathrm{cm}^{2}$ units were excavated (see Fig. 3). Although the frequency of lithic debris in these latter test units decreased drastically, concurrent survey operations even further westward onto the slopes of the adjacent uplands revealed extensive quarrying activity surrounding the stream drainage, often as much as $1000 \mathrm{~m}$ or more away from the water source.

The total of 11 shovel test units along the terrace implies much erosion along the banks of the present channel. The only diagnostic projectile point at the 
This page has been

redacted because it

contains restricted

information. 
This page has been

redacted because it

contains restricted

information. 
site has been identified as an Early Archaic Nolan dart point. This was found only $6 \mathrm{~cm}$ below the surface at Unit 3 . Although a moderate lithic scatter was found throughout the tested area of 3-1, subsurface evidence suggests most of the material has been eroded and scattered. No features were noted and no further work is recommended at this site.

\section{Site 3-3 (41 BX 444)}

The archaeological site of 3-3 was originally described as a small burned rock midden about $0.5 \mathrm{~m}$ in height and $10 \mathrm{~m}$ in diameter. The midden is located approximately $80 \mathrm{~m}$ eastward from the horseshoe bend of Salado Creek and roughly $300 \mathrm{~m}$ north through dense brush from the base of the high cliffs as the stream channel turns eastward.

Intensive survey throughout this locality and downstream toward $41 \mathrm{BX} 22$, the Rogers site, suggests this smal1 midden is part of a much larger activity area composed of an extensive lithic scatter. This runs the length of the north bank of the creek from the dam site area toward the large occupation site of $41 \mathrm{BX} 22,1.5 \mathrm{~km}$ downs tream. The large scatter of lithic debris may have at least four distinct localities along the bank which indicate areas of concentrated activity. Careful surface examination indicates that the small midden is located in the immediate proximity of a large lithic debris concentration that covers the entire eastern section of the bend, at least $200 \times 300 \mathrm{~m}$. Because of the extent of the 3-3 activity area, $50-\mathrm{cm}^{2}$ shovel tests were primarily used to test three specific locations in and around the midden (see Fig. 4).

A total of seven $50-\mathrm{cm}^{2}$ shovel tests and a $1-\mathrm{m}^{2}$ test unit were excavated at the midden. Soils in all units included a dark gray to black organic, unconsolidated (but moist) loam extending to an average depth below the surface of 20 to $24 \mathrm{~cm}$. Underlying this was a calcareous, lighter brown, compacted soil interspersed with cobble-sized limestone rocks. Artifacts and lithic debris recovered in all test units were found above this transition soil and usually within 12 to $15 \mathrm{~cm}$ of the surface. Only one diagnostic dart point was found during subsurface testing at the midden, although several other biface fragments were found in the same area during intensive surface survey operations (see Table 3). Frequency of most lithic debris recovered in the test units varied from light to moderate, although ST-14 (see Fig. 4) yielded five complete cores (10 to $18 \mathrm{~cm}$ in length) and seven large core fragments.

Eight other $50-\mathrm{cm}^{2}$ test units were excavated in two small clearings near the midden which, by subsurface indications, suggested possible occupation areas. Scattered biface fragments, numerous trimmed and/or utilized flakes and firereddened limestone rocks were found in this area. Subsurface examinations showed no cultural materials below a depth of $12 \mathrm{~cm}$ and a sterile, caliche-like strata at an average depth of 18 to $23 \mathrm{~cm}$.

Subsurface testing in and around the area originally described as 3-3 revealed no significant deposits of prehistoric cultural materials. Much of the area contains little soil depth and many of the materials are exposed on the surface through erosion. No further work is recommended at the archaeological site of 3-3 because of the large area and the dense brush in the vicinity of the site; it is suggested, however, that an archaeologist be present if the proposed dam site construction necessitates the presence of heavy machinery in the site area. 
This page has been

redacted because it

contains restricted

information. 


\begin{tabular}{|c|c|c|c|c|c|c|c|c|c|c|c|c|c|c|c|c|c|}
\hline \multirow{3}{*}{$\begin{array}{l}\text { TABLE } 3 \\
\text { PROVENIENCE OF } \\
\text { LITHIC MATERIALS } \\
\text { *All shovel tests }(5) \text { at this site } \\
\text { were sterile. }\end{array}$} & \multicolumn{5}{|c|}{ BIFACES } & \multicolumn{2}{|c|}{ UNIFACES } & & \multicolumn{3}{|c|}{ CORES } & \multicolumn{4}{|c|}{ FLAKES } & & \\
\hline & & & & & & & & & & & & & & Inte & & & \\
\hline & 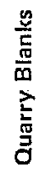 & 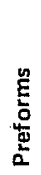 & 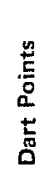 & 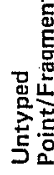 & 工 & 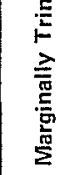 & 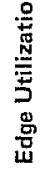 & 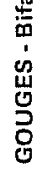 & $\begin{array}{l}\frac{m}{8} \\
\frac{8}{0}\end{array}$ & 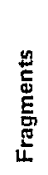 & 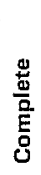 & 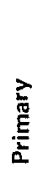 & 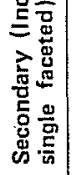 & $\begin{array}{l}\text { E } \\
\text { 妾 } \\
\frac{\mathrm{g}}{\mathrm{a}}\end{array}$ & 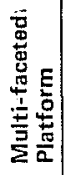 & 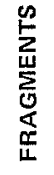 & $\overrightarrow{5}$ \\
\hline
\end{tabular}

\begin{tabular}{|c|c|c|c|c|c|c|c|c|c|c|c|c|c|c|c|c|c|c|c|c|}
\hline \multirow{30}{*}{ 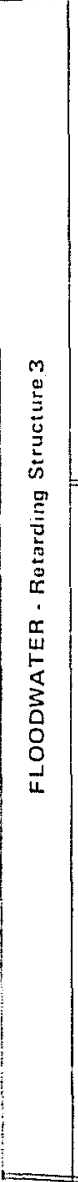 } & \multirow{12}{*}{$\begin{array}{l}\bar{m} \\
\stackrel{\Phi}{2} \\
\dot{5}\end{array}$} & \multirow{11}{*}{ 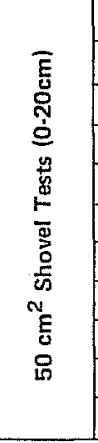 } & 1 & & & & & & & & & & & & 1 & 3 & 8 & & & 12 \\
\hline & & & 2 & & & & & & & & & & & & & 2 & 2 & & 1 & 5 \\
\hline & & & 3 & & & 1 & & & & & $\therefore$ & & & & 1 & 1 & 6 & & & 9 \\
\hline & & & 4 & & & & & 1 & & & 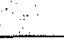 & & & & & & 1 & & & 2 \\
\hline & & & 5 & & & & & & & & & & & & & 1 & 5 & & & 6 \\
\hline & & & 6 & \multicolumn{2}{|c|}{ (Stefile) } & & & & & & & & & & & & & & & \\
\hline & & & 7 & & & & : & & & & & & & & 1 & 8 & 6 & & 5 & 21 \\
\hline & & & 8 & \multicolumn{2}{|c|}{ (Stepile) } & & & & & & & & & & & & & & & \\
\hline & & & 9 & & & & & & & & & & & & & & 3 & & & 3 \\
\hline & & & 10 & & & & & & & & & & & & & & & & 4 & 4 \\
\hline & & & 11 & (Ste & & & & & & & & & & & & & & & & \\
\hline & & \multicolumn{2}{|c|}{ TOTALS } & & & 1 & 1 & 1 & & & & & & & 3 & 15 & 31 & & 10 & 62 \\
\hline & \multirow{18}{*}{$\begin{array}{c}m \\
m \\
m \\
\stackrel{y}{*}\end{array}$} & \multirow{15}{*}{ 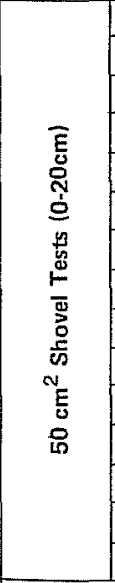 } & 1 & & & - & & & & & & & & & & & 2 & & 3 & 5 \\
\hline & & & 2 & & & & & & & & & & & & & & 4 & & 5 & 9 \\
\hline & & & 3 & & & & 2 & & & & & & & & & 1 & 4 & & 5 & 12 \\
\hline & & & 4 & & & & & & & & & & & & & 2 & 14 & & 3 & 19 \\
\hline & & & 5 & & & & & & & & & & & & & 1 & & & 5 & 6 \\
\hline & & & 6 & & & & & & & & & & & & & & 1 & & 1 & 2 \\
\hline & & & 7 & & & & & & & & & & & & & & & & 2 & 2 \\
\hline & & & 8 & & & & & & & & & & & & & & 1 & & & 1 \\
\hline & & & 9 & & & & & 1 & & & & & 7 & & & & 4 & & & 12 \\
\hline & & & 10 & & & & & & & & & & & 1 & & 2 & 2 & & 11 & 16 \\
\hline & & & 11 & & & & & & & & & & & & & 2 & 1. & & 13 & 16 \\
\hline & & & 12 & & & & & 2 & 1 & & & & 6 & & & & 1 & & 11 & 21 \\
\hline & & & 13 & & & & & & & & & & 3 & & & & 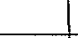 & & & 3 \\
\hline & & & 14 & & & 1 & & 1 & 2 & & & & 7 & 5 & & & 9 & & 35 & 60 \\
\hline & & & 15 & & & & & & & & & & & & & & & & 1 & 1 \\
\hline & & \multicolumn{2}{|c|}{$1 \mathrm{~m}^{2}$ Test Pit TP-1 } & & & & & & & & & 1 & & & & 2 & 4 & & 6 & 13 \\
\hline & & \multirow{2}{*}{\multicolumn{2}{|c|}{$\begin{array}{c}\text { Surface Collections } \\
\text { TOTALS }\end{array}$}} & & & 3 & & 2 & 4 & & 2 & & & & & & & & & 11 \\
\hline & & & & & & 4 & 2 & 6 & 7 & & 2 & 1 & 23 & 6 & & 10 & 47 & & 101 & 209 \\
\hline \multirow{8}{*}{ 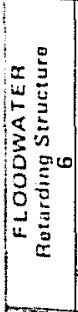 } & \multirow{7}{*}{ 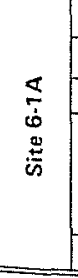 } & \multicolumn{2}{|c|}{$150 \times 50 \mathrm{~cm}$ Trench $A$} & & & & & & & 1 & & & & & 15 & 35 & 28 & 1 & 22 & 102 \\
\hline & & $1 \times 2 \mathrm{mT}$ & rench $B$ & & & 1 & & & & & & & 1 & & 1 & 19 & 35 & & 16 & 73 \\
\hline & & $1 \mathrm{~m}^{2} \mathrm{TP}$ & & & & & & & & & & & 1 & & & 14 & 41 & & 26 & 82 \\
\hline & & $N_{E} \bar{\Phi}, \overline{\text { 蒠 }}$ & 1 & & & & & & & & & & 1 & & & 7 & 10 & & & 18 \\
\hline & & 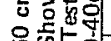 & 2 & & & & & & & & & & 3 & & 1 & 14 & 11 & & 10 & 39 \\
\hline & & Lin of & & & & & & & & & & & & & & 4 & 9 & & 2 & 15 \\
\hline & & & TTALS & & & 1 & & & & 1 & & & 6 & & 17 & 93 & 134 & 1 & 76 & 329 \\
\hline & Site 6-15 & $31 \mathrm{~m}^{2}(0-6$ & $40 \mathrm{~cm} / \mathrm{TP}-1$ & & 2 & & & & & & & & & & 2 & 94 & 270 & 4 & 55 & 427 \\
\hline$x \frac{9}{3}$ & & $1 \times 2$ & n TP-1 & & & & & & & & & & & & & 21 & 77 & & 5 & 103 \\
\hline & 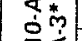 & $1 \times 2$ & $n$ TP-2 & & & & & & & & & & & & 10 & 7 & 10 & & 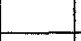 & 27 \\
\hline 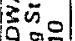 & $\underline{2} \approx$ & $1 \mathrm{~m}^{2}-$ & $\mathrm{PP}-3$ & & & & & & & & & 3 & 2 & & & 56 & 23 & & 6 & 90 \\
\hline 㛡 & is & TOT & LLS & & & & & & & & & 3 & 2 & & 10 & 84 & 110 & & 11 & 220 \\
\hline $4 \frac{5}{5}$ & : & $1 \mathrm{~m}^{2}$ & TP-1 & ISte & & & & & & & & & & & & & & & & \\
\hline & 00 & $1 \times 3 r$ & $n T P-2$ & 1 & 1 & & & & & & & 1 & & & 4 & 21 & 26 & & 7 & 61 \\
\hline 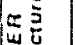 & 旁 & Area & $10 \mathrm{~m}^{2}$ & & & & & & 1 & & & & 8 & 2 & 3 & 2 & 7 & & 2 & 25 \\
\hline$\leqslant z$ & $m \bar{\Xi}$ & Area & A & & & & & & & & & & 4 & & 1 & 10 & & & & 15 \\
\hline $\mid$ & 佥 & Area & $\mathrm{B}$ & & 1 & & & & & & & 3 & 4 & & 3 & 10 & 2 & & & 23 \\
\hline $18 \overline{0}$ & ڤ̆ & Area & C & 1 & & & & & 1 & & & & & & & 1 & & & & 3 \\
\hline 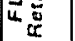 & 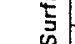 & & D & 1 & & & & 2 & & & & 1 & & & 1 & & & & & 5 \\
\hline & & TOT & ALS & 2 & 1 & & & 2 & 2 & & & 4 & 16 & 2 & 8 & 23 & \begin{tabular}{l|l}
9 \\
\end{tabular} & & 2 & 71 \\
\hline
\end{tabular}


Floodwater Retarding Structure 6

As discussed in Hester et al. (1974), the construction site for this floodwater retarding structure is located on Panther Springs Creek about $1.5 \mathrm{~km}$ south of FM 1604 and $68 \mathrm{~m}$ east of Blanco Road. The flood basin for the project will partially encompass margins of Fairway 7 of the Canyon Creek Country Club Golf Course and the terrace site of 6-2 (41 BX 363). The western edge of the project area is a prominent limestone bluff roughiy 10 to $15 \mathrm{~m}$ in height and immediately adjacent to the dry, boulder-strewn stream bed of Panther Springs Creek. Within this eroded bluff face and in the approximate center along the length of the bluff are the rockshelter sites of $6-1 A$ and $6-1 B(41 B X 362)$ (Fig. 5).

\section{Rockshelter 6-1 (Shelter A) (41 BX 362)}

Shelter $A$ is located about $4 \mathrm{~m}$ above and adjacent to the west bank of Panther Springs Creek. The shelter is composed of several snall, eroded cavities in the porous limestone bluff and consists primarily of two rooms separated by large boulders and rubble from past rock fall. Within the shelter, three small tunnels lead into small, rubble-filled cavities.

Subsurface examination of the rockshelter was conducted through the use of three $50-\mathrm{cm}^{2}$ shovel tests at 3-meter intervals along the talus slope, a $50 \mathrm{x}$ $150 \mathrm{~cm}$ trench (Trench $A$ ) in the narrow confines of the southern room, and by $1-\mathrm{m}^{2}(\mathrm{TP}-1)$ and $1 \times 2 \mathrm{~m}$ pits (Trench $\mathrm{B}$ ) in the slightly larger northern room. To establish a correlation of excavated depths between the separate rooms, a line and level were strung from the surface at the southwest corner stake of Test Pit 1 in the northern room to a point $121.5 \mathrm{~cm}$ above the floor and the northwest corner stake at Trench $A$ in the southern room (see Fig. 6).

\section{Trench A}

Due to natural irregularities in the shelter floor, subsurface examinations in the smal1 southern room took the form of a $150 \times 50 \mathrm{~cm}$ trench in a shallow soil deposit. Although bedrock-7ike limestone below $38 \mathrm{~cm}$ precluded further testing, materials excavated by trowels and screened through 1/8-inch fine wire mesh suggested the test area had been highly disturbed." While lithic debris was limited to a moderate scatter from the surface to $20 \mathrm{~cm}$, a small plastic bag and other recent refuse were found just above limestone at $30 \mathrm{~cm}$. Soils to the level of the presumed bedrock were identified in the field as an unconsolidated fine-grained, dark gray humus at the surface to a thin. lighter, calcareous transition just above the 7 imestone. No diagnostic artifacts were found at any level during the trench examination. A smali number of unidentified rodent bones were recovered scattered throughout the horizontal levels.

Test Pit 1

Test Pit 1 in the main shelter area was excavated as a $1-m^{2}$ just behind the large boulders partialiy blocking the entrance to the northern shelter area. As the testing progressed, it became obvious this pit area had been moderately to extensively damaged by recent disturbance. Modern trash in the form of glass and plastic was noted to depths exceeding $20 \mathrm{~cm}$, and, al though small charred wood fragments and lithic debris were also found, they were intermingled with cigarette filters and cellophane. A change in soil compactness occurred 
This page has been

redacted because it

contains restricted

information. 
This page has been

redacted because it

contains restricted

information. 
below $15 \mathrm{~cm}$ of the surface, and a small, curvilinear ash lens was exposed in the north wall of the test pit. While several chert flakes were in close association with this lens, no direct relationships could be identified. Several fragmentary, scattered and burned vertebrae and tarsal-like bones were found below the lens to a depth of almost $40 \mathrm{~cm}$. Frequency of lithic debris declined with an increase in depth, although a large chert core fragment was exposed in an apparently undisturbed context at $37 \mathrm{~cm}$. No diagnostic or finished artifacts were noted, and activity of this test pit ended at about $40 \mathrm{~cm}$ as a large limestone shelf, or possibly a portion of the bedrock floor, was exposed (see Fig. 7).

Trench B

On the basis of information gathered from Trench $A$ and Test Pit 1, a third $1-\mathrm{m}^{2}$ (later expanded to $1 \times 2 \mathrm{~m}$ trench) was excavated toward the rear of the main shelter area and away from the previously disturbed areas. Excavation by trowel revealed stratified deposits to a depth exceeding $40 \mathrm{~cm}$. Three distinct soil zones were noted at depths of 11,25 and $46 \mathrm{~cm}$ below surface (see Fig. 8). Excavations in this area were concluded at $46 \mathrm{~cm}$ due to the presence of a large limestone shelf extending across the floor of the pit.

Archaeological evidence consisted of a moderate scattering of lithic debris between 0 to $8 \mathrm{~cm}$ and within a soil transition zone (dark gray, organic soil to a yellowish orange, deteriorating limestone) at about 15 to $25 \mathrm{~cm}$ (see Fig. 8). An untyped, stemmed dart point, $4 \mathrm{~cm}$ in length, was recovered from this latter zone. Made from fine-grained, light brown chert, attributes of the point included parallel flaking and ground basal edges, suggesting possible Late Paleo-Indian affinity.

A preliminary analysis of artifacts and lithic debris from the rockshelter implies two prehistoric periods of light to moderate activity. The earlier occupation can be identified by the occurrence of a moderate lithic scatter just above presumed bedrock in Trench $B$ and in somewhat questionable association with an ash lens at 20 to $30 \mathrm{~cm}$ in Test Pit 1. Lithic debris in the form of interior flakes and chips was lightly to moderately patinated in both areas. A second period of occupancy is suggested by a series of secondary and interior flakes at or just below the surface.

Rockshelter 6-1 (Shelter B)

A second rockshelter was discovered during a casual reconnaissance in the vicinity of 6-1. Not previously identified, the second shelter was designated $6-1$, Rockshelter $B$ in the field. Rockshelter B is located approximately $40 \mathrm{~m}$ northward along the bluff face from Shelter $A$ and is situated $8 \mathrm{~m}$ above the now dry creek bed. OnTy $4 \times 3 \mathrm{~m}$ in length and width, the shelter nonetheless offers a limited amount of protection from the elements (Fig. 9). A $1-\mathrm{m}^{2}$ pit was excavated to a depth of $35 \mathrm{~cm}$ in the northern corner of the she1ter, revealing a high frequency of primary, secondary and tertiary flakes from 0 to $20 \mathrm{~cm}$. Utilized flakes, preform-like biface fragments and a crude biface fragment were recovered. Although oniy a limited examination was conducted at the site, the frequency and depth of artifacts suggest a potential for further excavation in order to evaluate the nature of prehistoric activity at the site. 


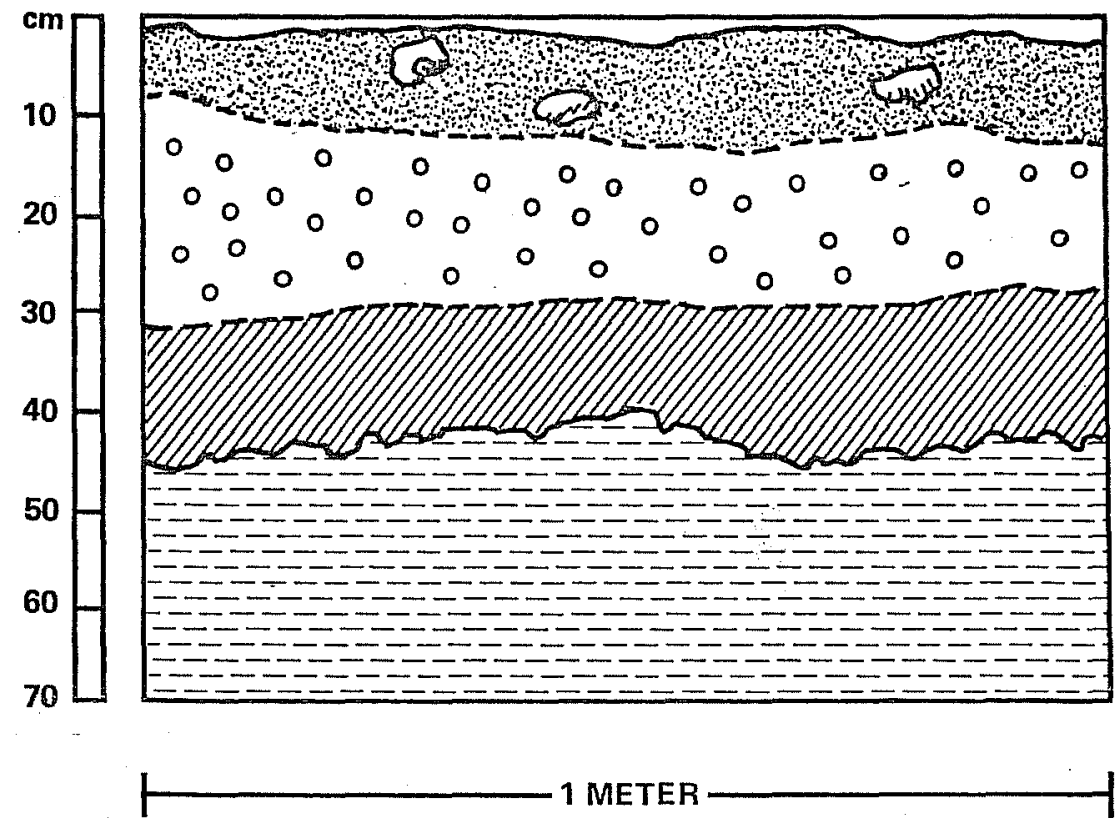

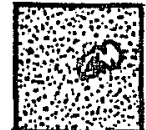

ORGANIC SOIL

MEDIUM TO DARK GRAY, POWDERY

$$
\begin{array}{lll|}
\hline 0 & 0 & \\
0 & & 0 \\
0 & 0 & 0 \\
0 & 0 & 0 \\
\hline
\end{array}
$$

TRANSITION ZONE

COMPACTED, MEDIUM TO LIGHT GRAY

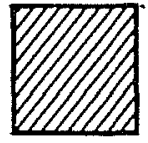

DETERIORATING LIMESTONE YELLOW-ORANGE CALCAREOUS

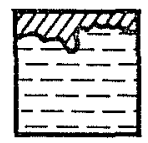

PRESUMED BEDROCK LIMESTONE

Figure 8. Profile of South wall Section of Trench $B$, Rockshelter 6-1A (41 BX 362). 


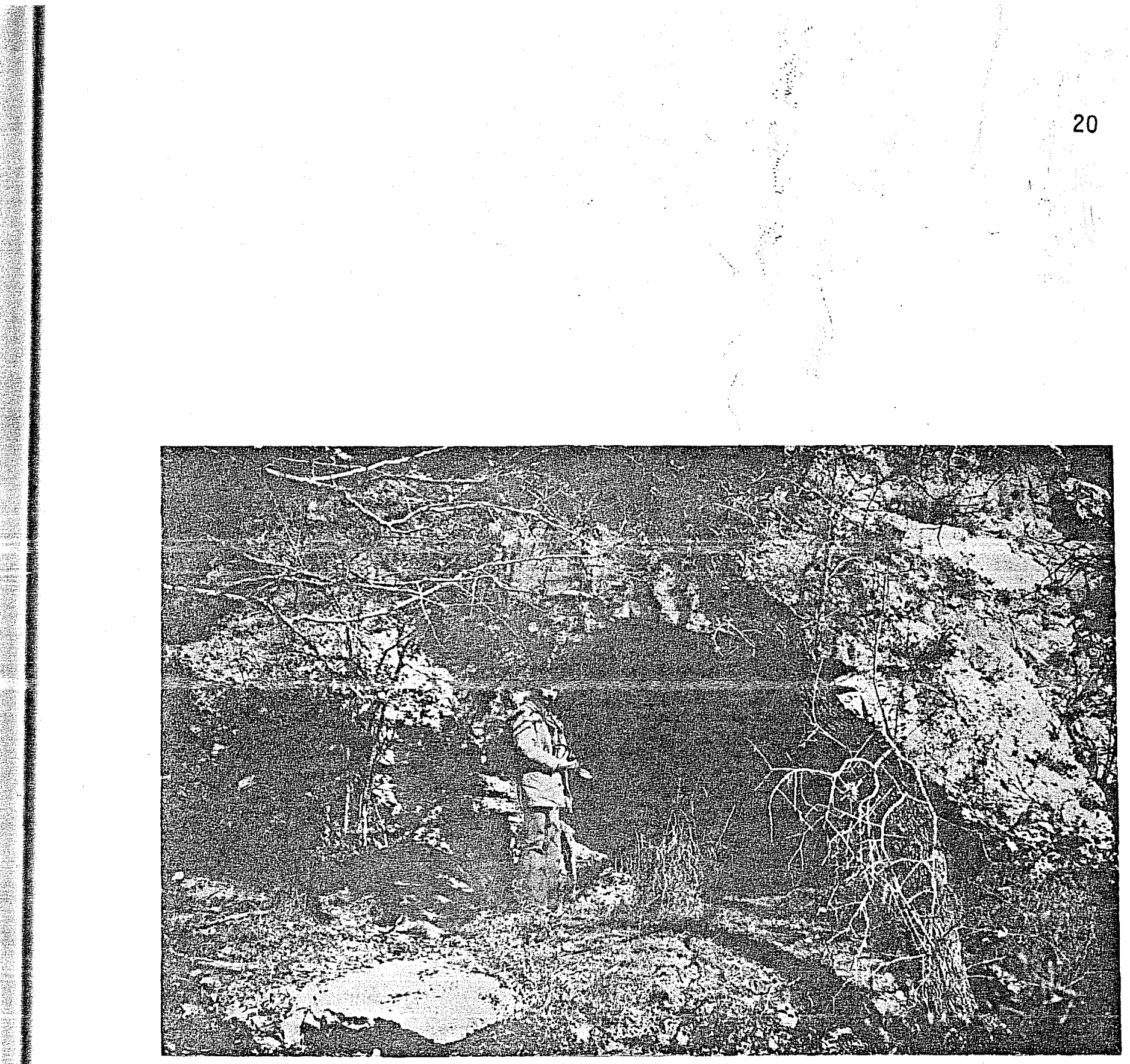

Figure 9. Rockshelter 6-1B (41 BX 362). 
Site 6-2 (41 BX 363)

First discovered in the preliminary survey of Panther Springs Creek in 1974, this terrace site was identified as an extensive scatter of burned rock and chert along the lower western and southwestern edges of Fairway 7 of the Canyon Creek Country Club Golf Course. Observations suggested the site to be $25 \times 75 \mathrm{~m}$ with possible hearths and some potential for depth (Fig. 10).

Present investigations in the form of an intensive survey and a series of $50-\mathrm{cm}^{2}$ shovel/trowel tests along the entire length of the site have revised the estimates of the original site. The survey redefined the site boundaries to about $150 \times 425 \mathrm{~m}$, or running the length of the terrace adjacent to the steep bluff face and Panther Springs Creek. No concentrations or possible hearths were noted, although several areas suggested chert quarrying activities. A systematic series of shovel tests spaced at $10-\mathrm{m}$ intervals was imposed over the largest of these quarry-like areas. In all shovel tests, limestone bedrock was reached within $30 \mathrm{~cm}$. A shallow, calcareous soil, dark to medium gray in color, extended to an average depth of $15 \mathrm{~cm}$ below the surface, where a reddish orange transition soil zone was found just above the limestone. In all cases, lithic debris was limited to the upper $8 \mathrm{~cm}$. No diagnostic artifacts were found through subsurface testing, although several crude, large biface fragments were found during intensive survey operations. To obtain the widest perspective possible of the entire site area and due to the lack of both artifacts and concentrations, five other $50-\mathrm{cm}^{2}$ test pits were established on a north-south axis at $50 \mathrm{~m}$ intervals to search for any additional evidence of former aboriginal activities. No diagnostic artifacts were found and only a few pieces of Tithic debris were noted during this phase of operations.

On the basis of intensive survey and limited testing operations, the original site description and size estimates for 6-2 have been modified as follows: it is a deflated quarry-workshop/terrace site with dimensions of ca. $150 \times 450$ meters. Whether the site once extended eastward from the slopes to the now heavily disturbed uplands of Fairway 7 cannot be accurately determined, although the continuation of lithic debris onto the margins of the golf course suggests this. The site area not altered by modification for golfing facilities seems heavily deflated by natural erosion. No further work is recommended at this site.

\section{Floodwater Retarding Structure 10}

An attempt to relocate the previously identified rockshelter known as site 10-3 (41 BX 452) along Mud Creek has led to the re-evaluation of the site as a whole. Originaliy described in the preliminary survey report as a small rockshelter located in the bluff above the northern bank of Mud Creek (roughly $400 \mathrm{~m}$ from the intersection of the creek with Jones Maltsberger Road), the site is actually composed of two rockshelter complexes about $40 \mathrm{~m}$ apart. The shelter complexes, designated as "A" and "B," are composed of three and two small shelters, respectively. Complex $A$ is" located in the immediate vicinity of large utility power iines as they intersect this portion of Mud Creek, and Complex $B$ is around $40 \mathrm{~m}$ southeast along the dry drainage channel (see Fig. 11). 


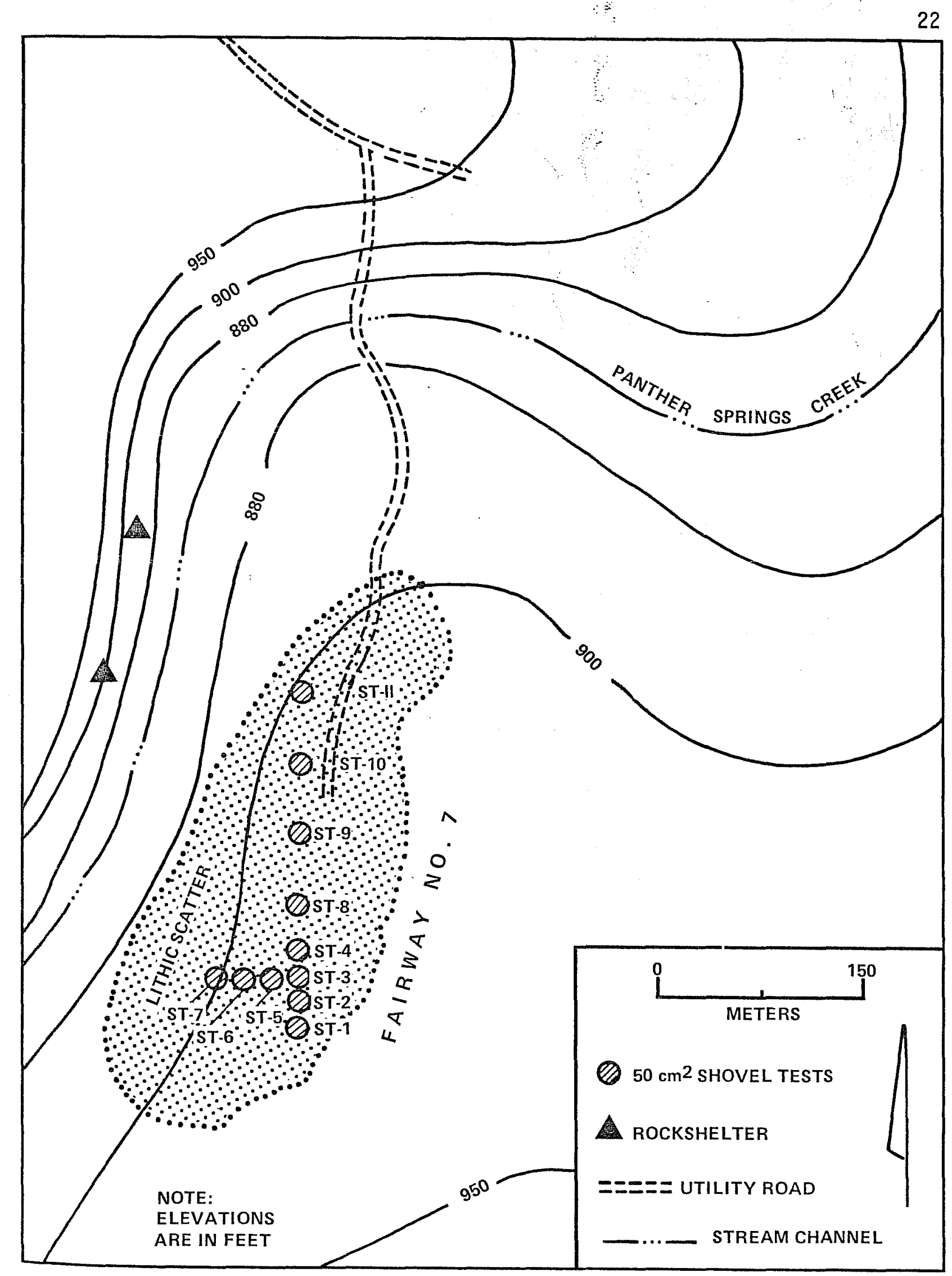

Figure 10. Map of Test units at Site 6-2 (41 BX 363). 
This page has been

redacted because it

contains restricted

information. 
Rockshelter Complex A

Complex $A$ consists of three small adjacent shelters (designated $A-1, A-2$ and $A-3$ located 3 to $5 \mathrm{~m}$ above the stream bed. The smallest of these is barely large enough to stand upright in, while the largest is $11 \times 9.5 \mathrm{~m}$ in length and width with an opening height of at least $10 \mathrm{~m}$ (see Fig. 12). Shelters $A-1$ and $A-2$ had smali openings with no evident talus slopes. One-m ${ }^{2}$ test pits were excavated in each shelter to depths of more than $40 \mathrm{~cm}$. No lithic debris or any other evidence of former occupation was noted at any level.

Rockshelter A-3 received intensive testing activity because of its attractive occupational features: spacious physical dimensions, accessibility to former water resources and protection from the elements. The interior of the shelter, where it had not been disturbed by previous rock falls, was almost completely excavated by trenches, $1-\mathrm{m}^{2}$ pits and a series of shovel tests (Fig. 13). Complete excavation of the small rockshelter was seriously limited by scattered, large sections of collapsed limestone from the ceiling. Small rodent and possible deer bones were scattered throughout the shelter, and a moderate scatter of 7 ithic debris was found to a depth of approximately $20 \mathrm{~cm}$ in all test pits and trenches. Buried ash lenses were uncovered in TP-1 and TP-3, in association with 7 ithic debris, suggesting moderate occupational activity. A heavily disturbed area about $1 \mathrm{~m}$ in diameter, presumably a relic collector's pit, was noted in the southern entrance of the shelter. A $50-\mathrm{cm}^{2}$ shovel test, later expanded into TP-3 $\left(1-\mathrm{m}^{2}\right)$, produced an intense concentration of lithic debris to a depth of $38 \mathrm{~cm}$; unfortunately, evidence of modern disturbance was noted through most of this depth. No diagnostic artifacts were noted in any of the subsurface examinations at any depth.

The results of test pits and shovel tests suggest the rockshelter was a moderately occupied prehistoric activity center reflecting specific areas for intrasite activities; two ash lenses, one at the entrance of the shelter and the other at the rear, suggest possible campfires, al though no temporal conclusions can be drawn between or from them. An intense area of lithic reduction activities was identified in the southern entrance area. No other area of the shelter reflected such specific or intensive activity, although portions of collapsed limestone from the ceiling may hide further aboriginal deposits. No further work is recommended at this site.

Rockshelter Complex $B$

Rockshelter Complex $B$ consisted of two small shelters, designated in the field as $B-1$ and $B-2$. B-1, a shallow linear shelter $16 \times 10 \mathrm{~m}$, was tested by a systematic series of $50-\mathrm{cm}^{2}$ shovel tests. All test areas were tested to bedrock and were sterile. It is possible the large amounts of powdery limestone dust accumulating on the floors imply rapid deterioration or collapsing of the sheiter roof.

$\mathrm{B}-2$ (Fig. 14) was a smaller shelter adjacent to $\mathrm{B}-1$, and a $1-\mathrm{m}^{2}$ test pit inside the $4 \times 6$ m cavity revealed less than $5 \mathrm{~cm}$ of soil deposits over presumed bedrock or a large limestone shelf covering the floor of the cavity. A $1 \times 3$ trench on the talus slope, $8 \mathrm{~m}$ in front of the entrance, uncovered one of the most 


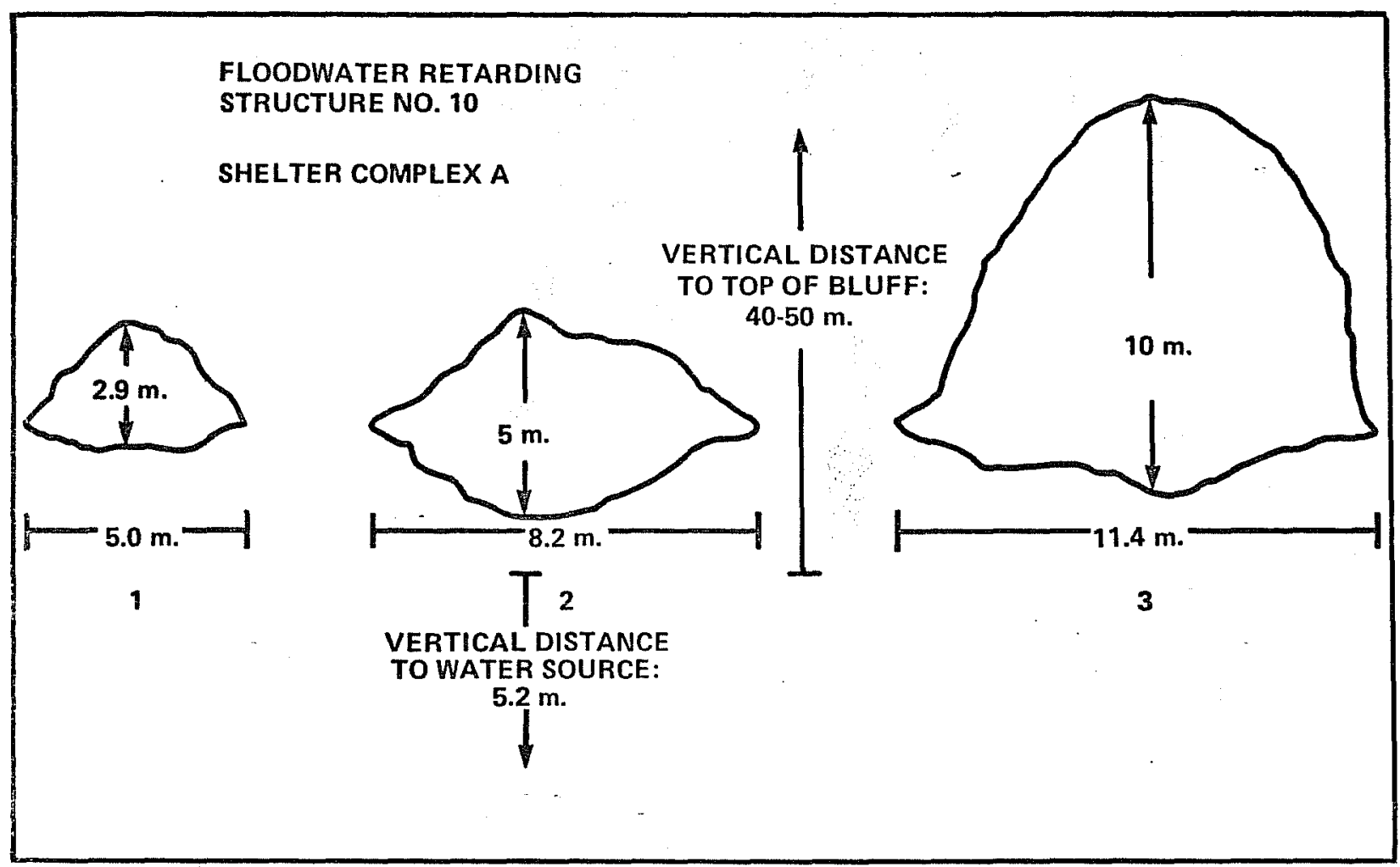

a

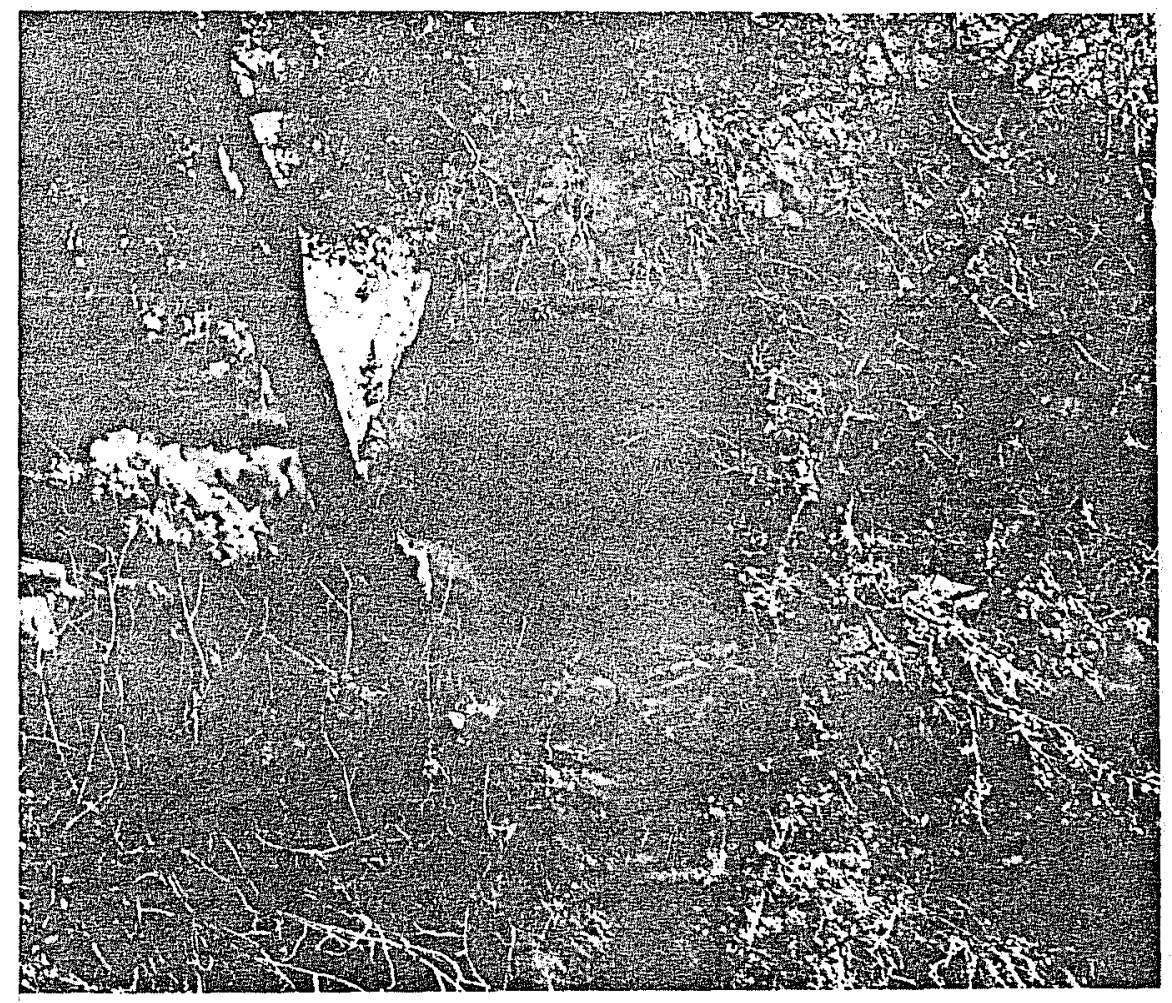

b

Figure 12. Rockshelter Complex 10-3A (41 BX 452). a, elevations of the three shelters in Complex $A(A-1, A-2, A-3) ; b$, view of entrance to Rockshelter A-3. 
FLOODWATER RETARDING STRUCTURE NO. 10

ROCKSHELTER COMPLEX A; TOP VIEW, SHELTER 3

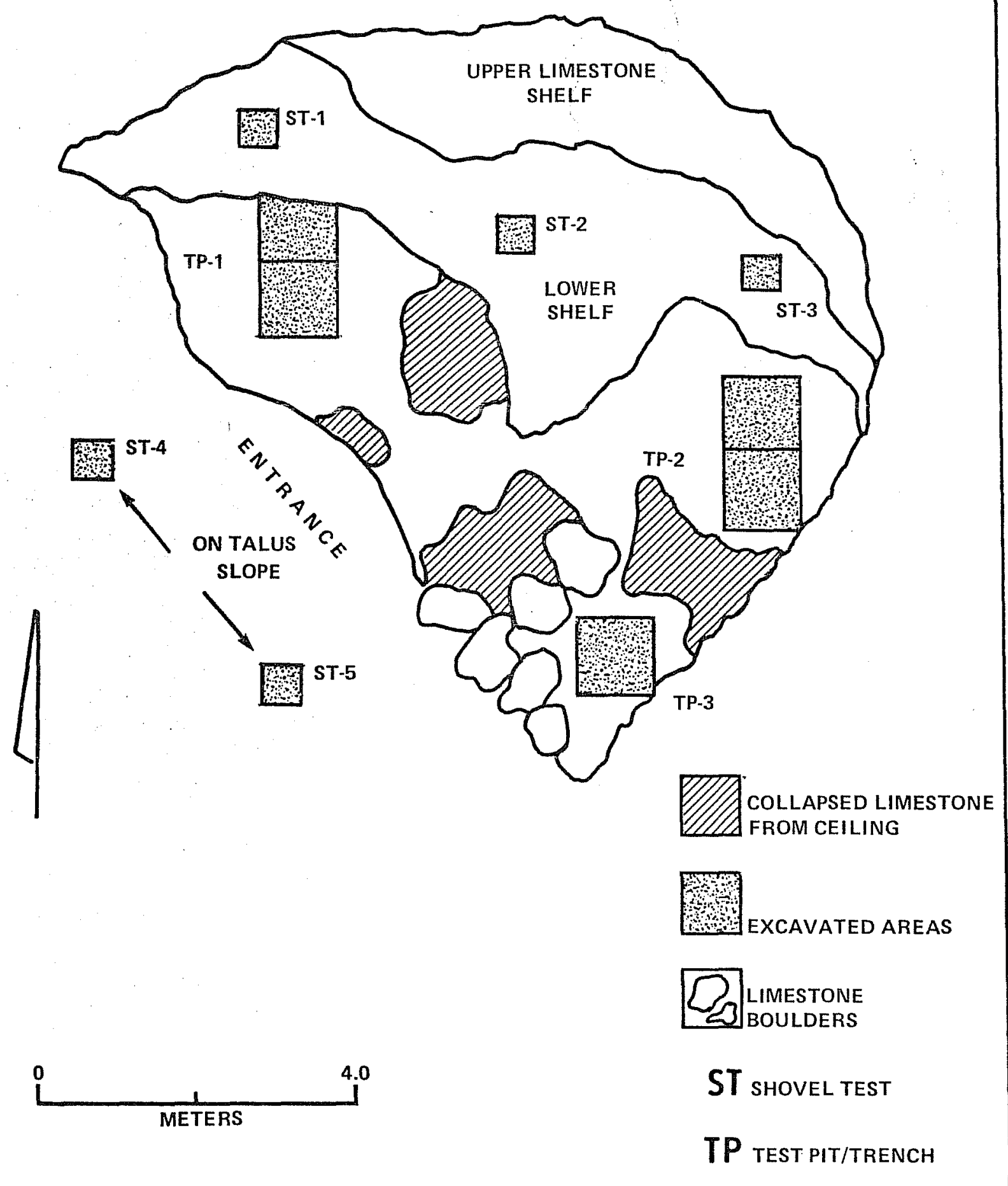

Figure 13. Map of Test units at Rockshelter A-3, Complex 10-3A (41 BX 452). 


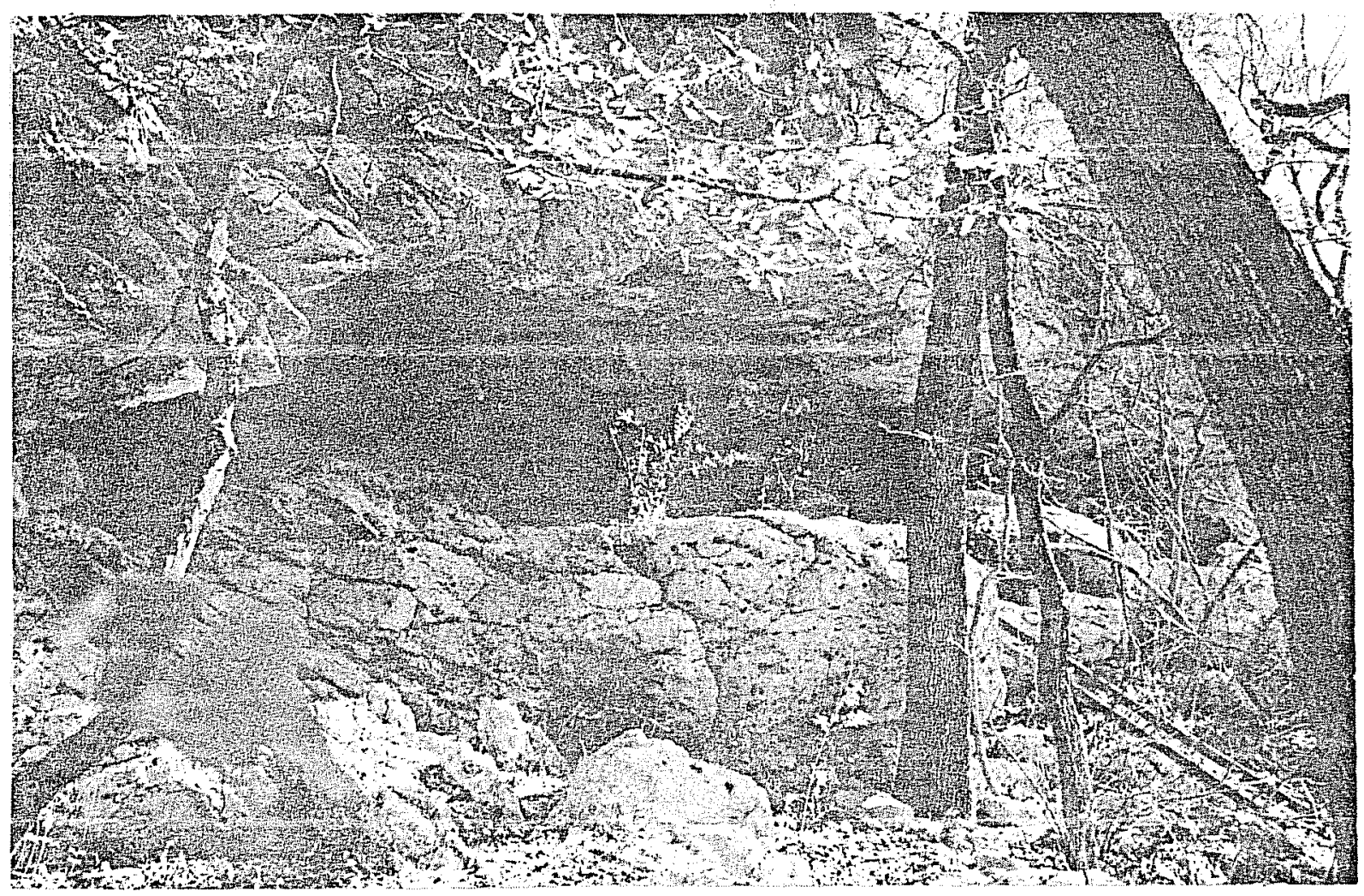

Figure 14. View of Rockshelter B-2, Complex 10-3B, Looking North. 
intensive concentrations of Tithic debris found in any pit during the entire testing operation. Utilized flakes, unifacial end scrapers and a preformlike biface were scattered among the relatively large collection of chips and flakes. Because of time limitations; no further work was done to expand the investigation of this previously unrecorded shelter. The frequency and depth of 7 ithic debris and artifacts suggest a potential for further research of the shelter entrance and talus slope to define the intensity and extent of this unusual site.'

\section{Floodwater Retarding Structure 15}

Floodwater Retarding Structure 15 and the archaeological site of 15-3 (41 BX 173) are located adjacent to the eastern exit road of Northeast Preserve and its junction with the intermittentiy running stream channel of Mud Creek. The site extends aiong and away from a high terrace of Mud Creek in the northeast section of the park. Results of an intensive survey suggest site dimensions as large as $375 \times 250 \mathrm{~m}$, most of this composed of a lithic scatter derived from light to moderate quarrying/workshop activities. No diagnostic artifacts were noted throughout this area other than several widely scattered crude biface fragments and gouge-7ike tools. The present site boundaries include Mud Creek to the west, a plowed field to the north, large utflity power lines to the east and an exit road to the park in the south (see Fig. 15). Large cores collected from the field south of the road suggest the original site dimensions may have been much larger than presently observed, although the archaeological value of this southern area has been completely destroyed by modern alterations.

The large areal extent of the site and dense brush complicated the intensive survey operations. No concentrations of diagnostic projectile points were recovered, aithough several clear Fork and Guadalupe-like tools were observed in the northwest margins of the site along gullies and eroded run-offs, suggesting a possibility for further research in the form of limited subsurface testing to determine their significance.

A $10-m^{2}$ area, arbitrarity chosen in the center of the study area, became the focus of a controlled surface collection operation to determine the actual number and types of lithic debris to be found on the surface of the study area (Fig. 16). The collected area did not reflect any difference in features or special characteristics; rather, the collection area was seemingly indistinguishable both in frequency and types of artifacts and debris from the rest of the site area.

It must be realized that the data from such a sample does not provide an unbiased sample of the total lithic materials present, and the 1fmitations and selection of the sample are in general inadequate and inappropriate for a more detailed quantitative approach. The current collection, however, was considered adequate for the type of evaluative operation involved in this project. Investigation of 15-3 was severely limited in both time and manpower, making it impossible to spend the necessary effort to choose and research a sufficient portion of the site from which to derive statistically reliable data. Rather than selecting an area haphazardly, the investigators' past experience and their familiarity with quarry/workshop sites were used to choose, via a 
This page has been

redacted because it

contains restricted

information. 


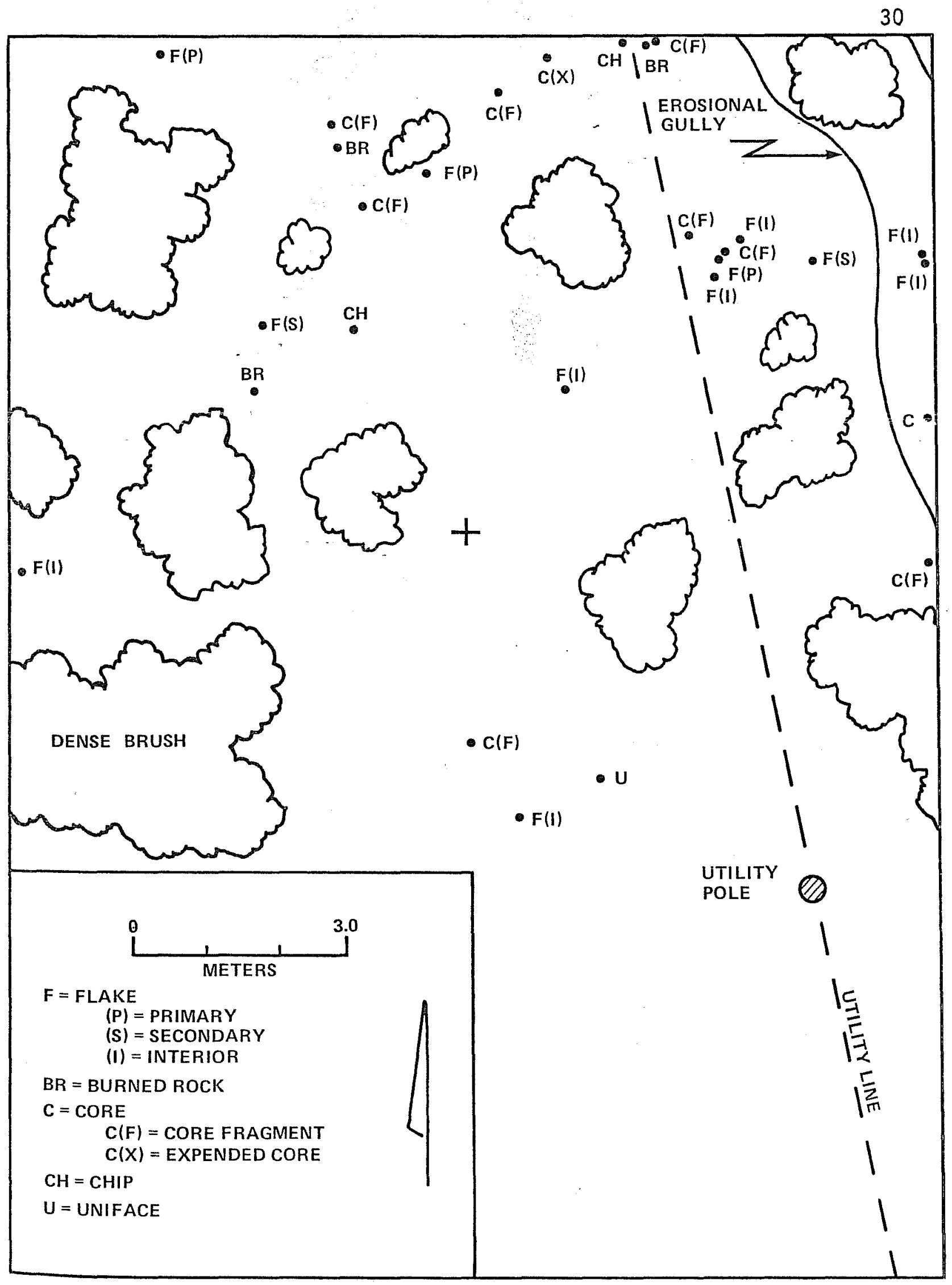

Figure 16. Site 15-3 (41 BX 173). Plan of controlled surface collections within a $10-\mathrm{m}^{2}$ area. 
"judgment sample," an area for study. Past research shows that while this design should not be construed as an accurate statistical approximation of the total lithic material, it can be of considerable value (Redman 1974).

A redefinition of site $15-3$ suggests the site was once a quarry/workshop zone extending from 400 to $600 \mathrm{~m}$ along the eastern terrace of Mud Creek and at least $250 \mathrm{~m}$ away from it. Prehistoric activity in the area is extensive rather than intensive and no major concentrations or features were noted. Further evidence of site activity may be hidden beneath a light soil cover, especially evidence of occupation in the northwest margins of the site area. Intensive surface survey operations in this area observed fire-reddened rocks that appeared to be eroding along the slopes. We recommend limited testing in the form of $1-\mathrm{m}^{2}$ and $50-\mathrm{cm}^{2}$ shovel tests in this potential occupation area to define the extent, depth and spatial relationships, and to permit an evaluation of National Register eligibility.

\section{LITHIC ANALYSIS}

This study will attempt only a preliminary examination of the lithic materials collected throughout the field operations. Distinctive attributes of major artifact and debris categories will be noted as to provenience and frequency, and a brief description will define each category. Summary statistics of 1ithic data are presented in Table 3. Additional descriptions, statistical data and collected materials are also on file at the Center for Archaeological Research, The University of Texas at San Antonio.

For purposes of this study, many artifact and debris categories can be defined on the degree and type of retouch. Retouch in this analys is generally refers to the detachment of small flakes from a point or tool for the purpose of edge alteration, resharpening or strengthening. The result of this action is flake scars on dorsal or ventral ends or sides of the material. This section has divided the materials into two general groups: (1) cores and lithic debris and (2) unifacial and bifacial artifacts. Examples of artifacts collected are presented in Figures 17 and 18.

Cores and Lithic Debris

A total of 59 cores and core fragments and 645 pieces of lithic debris were recovered from the testing operations. These materials have been separated into cores, core fragments, core tools and expended cores. Lithic debris refers to primary, secondary and tertiary (interior) flakes and miscellaneous chips or chunks.

\section{Cores}

Cores are pieces of siliceous stone used as raw material for various types of lithic reduction processes. They often exhibit at least one flat surface from which one or more pieces (flakes) have been detached and do not exhibit any butbs of percussion. The subcategory of core tools is described as still 

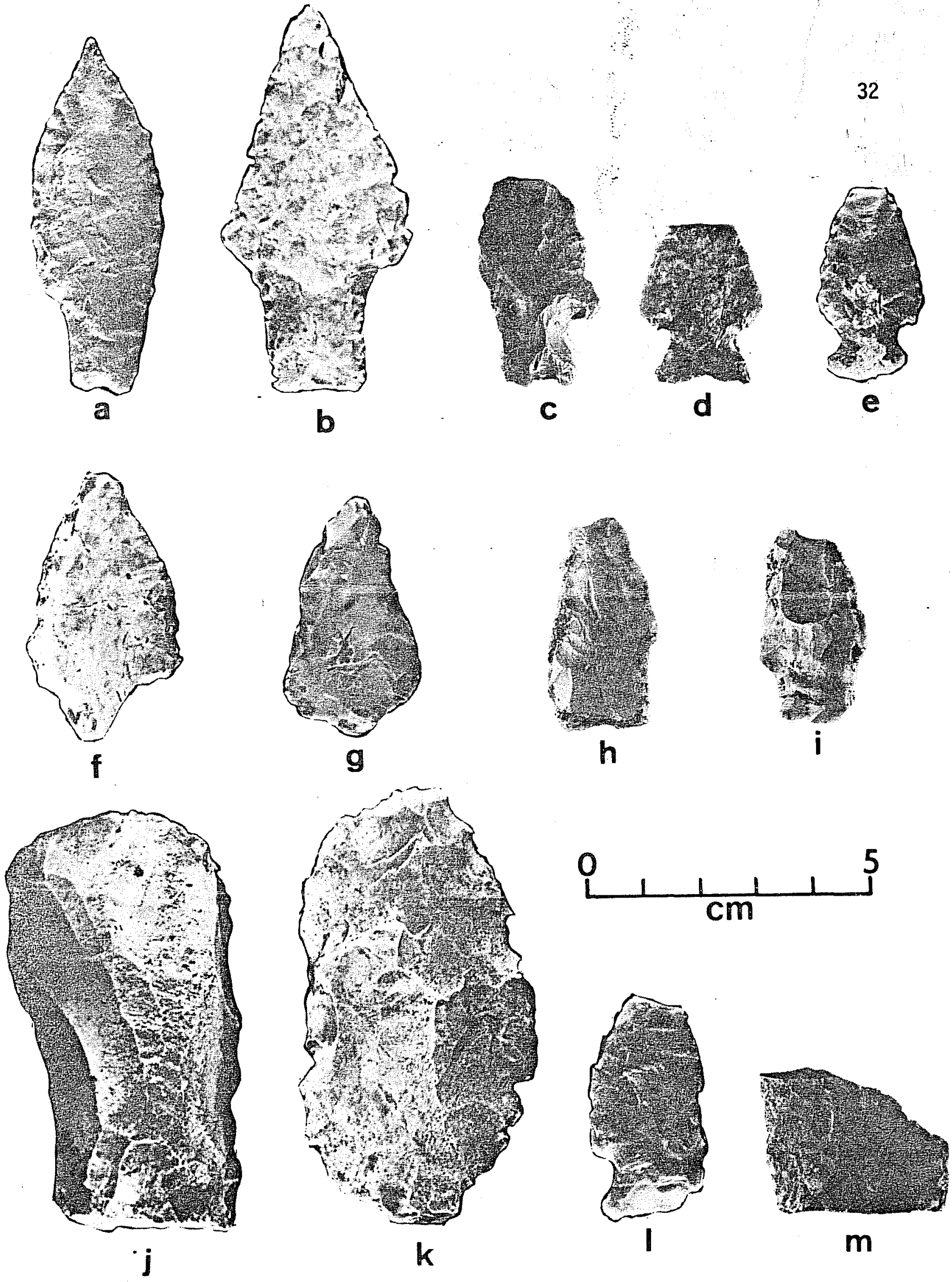

Figure 17. Artifacts from Floodwater Retarding Structures 3 and 6 .

a, unclassified dart point (Rockshelter 6-1A, Trench B); b, Nolan dart point (3-1, Shovel Test 3); c,e, corner-notched dart points; d, Martindale; $f-i$, preforms; $j$, gouge-like unifacial tool; $k$, ovate biface with extensive dorsal retouch ( $c-k, 3-3$, surface) $1, \mathrm{~m}$, unclassified projectile points 

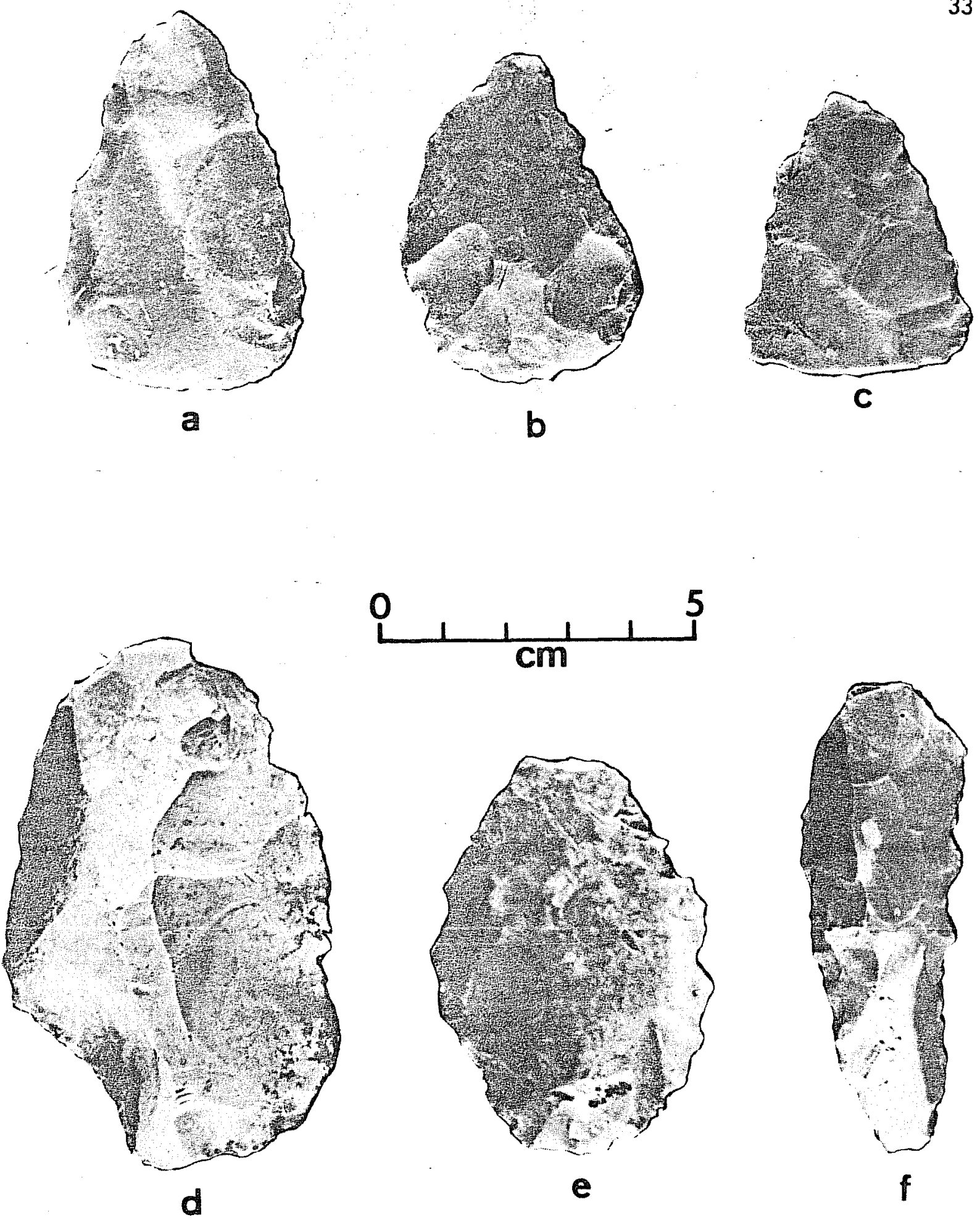

Figure 18. Artifacts from Floodwater Retarding Structures 6, 10 and 15 . a, preform (Rockshelter 6-1B, Test Pit 1); b, preform (15-3, Area B); $c$, distal biface fragment (10-3B, Shelter $B-2)$; d, core tool (15-3, Area $B)$; $e$, ovate biface (15-3, surface); $f$, unifacial gouge (15-3, Area C). 
identifiable cores which reflect marginal retouch modification or wear (observable alteration caused by utilization) along; portions of edge surfaces.

\section{Lithic Debris}

Debris in the form of smal1 pieces or flakes detached from a core often reflects both the type of lithic reduction technique and the extent of the reduction process. Through the examination of various attributes, a single piece of debris can be associated with one of a series of sequential stages of tool manufacture, and extended research can often discern the overall strategy of manufacture. For the purposes of this report, debris in the form of flakes has been divided into three general types based on the absence or presence and degree of exterior (cortex) surface: (1) primary flakes with cortex covering their dorsal surface; (2) secondary flakes, with some cortex; and (3) interior (tertiary) flakes that have no cortex on their dorsal surface. Flakes exhibit various types and sizes of platforms, remnants of the original striking platform of the core from which the flake was detached. Table 3 reflects one attribute of flake platforms in the form of single platforms or multi-faceted platforms. Multi-faceted platforms exhibit small scars as a function of prior retouch to build a prepared platform.

\section{Unifacial and Bifacial Artifacts}

These artifacts reflect trimming or utilization on dorsal and/or ventral surfaces and may be grouped into such categories as scrapers, gouge-1ike tools, projectile points and other thicker bifaces. The term uniface may apply to any non-formalized unifacially worked toot. Other categories briefly described include:

\section{Scrapers}

Scrapers may exhibit either unifacial or bifacial modifications, and steep retouch and wear patterns are often common along sides and/or edges in the form of step fractures and/or polish.

\section{Gouge-like Tools}

Gouge-1ike artifacts can be considered a specialized tool form as discussed by Epstein (1969) and Hester and Kohnitz (1975). They may be unifacial or bifacial and rectangular or triangular in form.

\section{Projectile Points}

Projectile points are thin, bifacially worked artifacts, presumably for use as dart or arrow points. In most cases basal modification has been in the form of corner or laterally-situated notches which result in distinctive stems. 
Other Bifaces

Other bifaces in this study were sorted into one general category. These artifacts are usually cruder and thicker in workmanship than the thinner projectile points and encompass such groups as preforms, quarry blanks and large knife-like bifacial tools. Unfinished bifaces often reveal specific phases of tool manufacture and types of former site workshop activity.

\section{SUMMARY AND RECOMMENDATIONS}

In general terms, al7 the sites investigated during the course of this study fall into Fawcett's (1972) "Northern Zone" characterized by intermittent water resources, upland chert sources and a presumed prehistoric emphasis on hunting (vs. riverine) subsistence. Of the two types of sites studied, terrace and rockshelter, the former is the more common throughout the area. The terrace sites investigated during current examinations were always hundreds of meters in length and may be more specifically considered as aboriginal activity areas with wide spatial and temporal characteristics. The most intensively investigated terrace site was located in the vicinity of Floodwater Retarding Structure 3, and these brief observations may be generally applied to other terrace sites examined.

The intensive activity reflected on the surface in the vicinity of 3-3 and along the terrace site of 3-1 suggests the entire stream valley in this locality, rather than being a single site area, was a preferred activity zone encompassing various prehistoric interests and not limited to simple quarry/ workshop processes. Gerstle, Kelly and Assad (1978) suggest the five sites previously recorded in the area of Floodwater Retarding Structure 3 may actually be small satellite localities from the major occupation site of $41 \mathrm{BX} 22$, the Rogers site, roughly 800 to $1000 \mathrm{~m}$ downstream. While this may in part explain the intense activity, there is no substantiated evidence to support this hypothesis, and it may be the area was exploited not only by the peoples of 41 BX 22 but also by those from the temporally distinct large site of 41 BX 36 located upstream. Nolan and Martindale projectile points recovered in subsurface testing of the area can be more reasonably linked to the Early Archaic occupations of $41 \mathrm{BX} 36$.

Interest southward from $41 \mathrm{BX} 36$ toward the dam site area can partially be explained by the absence of chert-bearing strata north of 41 BX 36 and the abundance of the same just southward. Unfortunately, the natural concentration of upland chert sources does not explain lower terrace activities along the drainage at which both the Nolan and illartindale points were recovered. Gerstle, Kelly and Assad (1978) tentatively suggest chert exploitation may have shifted in Early Archaic times along this area of the drainage, emphasizing resource exploitation in the lowland areas. Whatever the reasons, during Nolan and Martindale culturally affiliated periods, the lowland resources of this stream valley were obviously exploited. A further discussion of settiement patterns and lithic studies from the sites of the current study is beyond the present scope of the report, although it may be extracted from this study at a later date. It should be noted Hester (1976) emphasizes several characteristics of Archaic occupations in south Texas that are often 
reflected in the study area of the Salado Creek drainage: (1) the heterogeneity of aboriginal settlement patterns from one drainage to another, perhaps due to temporal differences but which may reflect adaptations to local environmental conditions; (2) an emphasis on placing sites within access to several micro-environments; (3) intrasite planning; and (4) the functional differences of sites.

In the course of present investigations along the Salado Creek drainage, two rockshelters, two rockshelter complexes and a total of four terrace sites were tested at Floodwater Retarding Structures 3,6, 10 and 15. The results of these tests are summarized in Table 4 . Four individual sites are recommended for further examination and their archaeological importance is discussed below.

Site $6-1$ (41 BX 362)

Rockshelters $6-1 A$ and $6-1 B$; further examination for complete excavation by $1-\mathrm{m}^{2}$ and $50-\mathrm{cm}^{2}$ units.

The writers recognize that the rockshelter sites of 6-1 lie outside the jurisdiction of the Soil Conservation Service because of (1) the sites' elevations above the planned maximum flood pool level (913.9 ft.) and (2) the sites' location on private property. Therefore, recomendations cannot be made that are applicable to any particular agency or individuals. However, these sites are included in Table 4 because of their potential importance to Bexar County prehistory and to point out the value of these rockshelters in further problemoriented studies of south central Texas archaeology.

Site $10-3(41 \mathrm{BX} 452)$

Rockshelter B-2 of rockshelter complex 10-3B; extensive testing of talus slope and the area of $\mathrm{B}-2$ to further determine the significance of the deposits.

Site 15-3 (41 BX 173)

We recommend 7 imited subsurface examination of this extensive terrace site at specific points to determine the depth and extent of deposits before destruction or alteration occurs. The unusually large site area possibly includes prehistoric lithic workshop activity and buried occupational deposits.

Because of time limitations under which field operations were conducted at this extensive site, the researchers were not able to adequately determine whether or not $41 \mathrm{BX} 173$ may be considered eligible for nomination to the National Register of Historic Places. A program of additional limited testing is recommended to determine the overall significance of this site.

A summary of this testing operation cannot be complete without a brief comment on the significance of the three small rockshelters recommended for further study. The importance of these sites can best be understood by approaching them from the perspective of south central Texas archaeology generally, and the archaeology of the Edwards Plateau/Coastal Plains transitional zone specifically. 
Unfortunately, for a variety of reasons, the role of the rockshelter during these times is little understood in relation to changing environmental conditions, aboriginal social structures, subsistence patterns or intrasite planning. Sma11, minimally disturbed shelters reflecting prehistoric activities are an unwritten record from which to better understand aboriginal lifeways. Rockshelters in Bexar County as a whole have been little explored and, consequently, little understood. They have, however, been subjected to much disturbance by relic collectors, campers and vandals. The appearance of such resources, as in the current investigations at Panther and Mud Creeks along the Salado drainage, should shed new light on this facet of prehistoric occupation activities. 
TABLE 4. SITE INFORMATION SUMMARIES

\begin{tabular}{|c|c|c|c|c|c|c|c|c|c|c|}
\hline \multirow[t]{2}{*}{ Site \# } & \multirow[t]{2}{*}{$\begin{array}{l}\text { Type of } \\
\text { Site }\end{array}$} & \multirow[t]{2}{*}{$\begin{array}{l}\text { Approximate } \\
\text { Elevation } \\
\text { (msi) }\end{array}$} & \multirow[t]{2}{*}{$\begin{array}{l}\text { Horizontal } \\
\text { Extent } \\
\text { (m) }\end{array}$} & \multirow[t]{2}{*}{$\begin{array}{l}\text { Drainage } \\
\text { Systent }\end{array}$} & \multicolumn{2}{|c|}{$\begin{array}{l}\text { Distance } \\
\text { From Water } \\
\text { Source (mi) }\end{array}$} & \multirow[t]{2}{*}{$\begin{array}{l}\text { Observed/ } \\
\text { Excaveted } \\
\text { Material }\end{array}$} & \multirow{2}{*}{$\begin{array}{l}\text { Archaeological } \\
\text { Potential } \\
\text { (Site Condition) }\end{array}$} & \multirow[t]{2}{*}{$\begin{array}{l}\text { Description } \\
\text { of Further } \\
\text { Work Needed }\end{array}$} & \multirow[t]{2}{*}{ Conments } \\
\hline & & & & & (v) & (H) & & & & \\
\hline $3-1$ & $\begin{array}{l}\text { Extensive } \\
\text { terrace, } \\
\text { workshop, } \\
\text { possible } \\
\text { occupation }\end{array}$ & $980-1010^{\prime}$ & $\begin{array}{l}(\text { mininum of }) \\
250 \times 300\end{array}$ & $\begin{array}{l}\text { Salado } \\
\text { Creek } \\
\text { (main } \\
\text { channel) }\end{array}$ & $2-10$ & $5-1000$ & $\begin{array}{l}\text { Extensive lithic } \\
\text { debris throughout } \\
\text { area, artifacts } \\
\text { include biface } \\
\text { fragnents, hurned } \\
\text { rock. }\end{array}$ & $\begin{array}{c}\text { See text. } \\
\vdots \\
\ddots\end{array}$ & No further work. & See text. \\
\hline $3-3$ & $\begin{array}{l}\text { Sirall burned } \\
\text { rock midden } \\
\text { and adjacent } \\
\text { terrace } \\
\text { activity } \\
\text { areas }\end{array}$ & $970-1010^{\prime}$ & $\begin{array}{c}(\operatorname{mininum} \text { of }) \\
200 \times 300 \\
-\end{array}$ & $\begin{array}{l}\text { Salado } \\
\text { Creek } \\
\text { (main } \\
\text { channe) }\end{array}$ & 375 & $0-300$ & $\begin{array}{l}\text { Burned rock, ex- } \\
\text { tens ive lithic } \\
\text { debris, biface } \\
\text { fragments. }\end{array}$ & See text. & No further work. & $\begin{array}{l}\text { Although no } \\
\text { work is recom- } \\
\text { mended, it is } \\
\text { suggested an } \\
\text { archaeologist } \\
\text { be present if } \\
\text { subsurface al- } \\
\text { teration occurs } \\
\text { in the form of } \\
\text { land moving or } \\
\text { borrow-fill. }\end{array}$ \\
\hline $6-]^{\star}$ & $\begin{array}{l}\text { Rockshel ter } \\
\text { (A) }\end{array}$ & $935^{\prime}$ & $12 \times 14$ & $\begin{array}{l}\text { Panther } \\
\text { Springs } \\
\text { Creek } \\
\text { (now dry) }\end{array}$ & 8 & 3 & $\begin{array}{l}\text { Dart point, ex- } \\
\text { tensive lithic } \\
\text { debris; possible } \\
\text { hearth. }\end{array}$ & $\begin{array}{l}\text { Site reflects moder- } \\
\text { ate disturbance in } \\
\text { upper } 10-\mathrm{cm} \text { level: } \\
\text { however, depth of } \\
\text { artifacts exceeds } \\
25 \mathrm{~cm} \text {. }\end{array}$ & $\begin{array}{l}\text { Continuation of } \\
\text { shel ter excava- } \\
\text { tion by } 1-\mathrm{m}^{2} \\
\text { pits to bedrock } \\
\text { for a better } \\
\text { perspective of } \\
\text { a Late Paleo/ } \\
\text { Pre-Archaic oc- } \\
\text { cupation. }\end{array}$ & $\begin{array}{l}\text { Total occupa- } \\
\text { tional area is } \\
\text { small and fur- } \\
\text { ther work for } \\
\text { complete exca- } \\
\text { vation is rela- } \\
\text { tively modest. }\end{array}$ \\
\hline $6-1^{\star}$ & $\begin{array}{c}\text { Rockshe] ter } \\
(B)\end{array}$ & $935^{\prime}$ & $4 \times 3$ & $\begin{array}{l}\text { Panther } \\
\text { Springs } \\
\text { Creek } \\
\text { (now dry) }\end{array}$ & 8 & 2 & $\begin{array}{l}\text { Preform; exten- } \\
\text { sive lithic } \\
\text { debris. }\end{array}$ & $\begin{array}{l}\text { Shelter is moderately } \\
\text { disturbed, upper } \\
\text { lo cni unusual fre- } \\
\text { quency of subsurface } \\
\text { artifacts suggests } \\
\text { potential for further } \\
\text { investigation. }\end{array}$ & $\begin{array}{l}\text { Continuation of } \\
\text { I-m test pits } \\
\text { for total exca- } \\
\text { vation of } 4 \times 3 \mathrm{~m} \\
\text { shelter. }\end{array}$ & \\
\hline $6-2$ & $\begin{array}{l}\text { Terrace, } \\
\text { moderate } \\
\text { quarry/ } \\
\text { workshop } \\
\text { activities }\end{array}$ & $900-920^{\prime}$ & . & $\begin{array}{l}\text { Panther } \\
\text { Springs } \\
\text { Creek } \\
\text { (now dry) }\end{array}$ & $0-$ & $0-31$ & $\begin{array}{l}\text { Extensive lithic } \\
\text { debris over wide } \\
\text { area; core frag- } \\
\text { ments; prinary. } \\
\text { secondary, terti- } \\
\text { ary flakes. }\end{array}$ & $\begin{array}{l}\text { Eastern edge of site } \\
\text { destrayed by modern } \\
\text { alteration. }\end{array}$ & No further work. & $\begin{array}{l}\text { Depth and fre- } \\
\text { quency of exca- } \\
\text { vated artifacts } \\
\text { are minimal. }\end{array}$ \\
\hline $10-3$ & $\begin{array}{l}\text { Rocksheiter } \\
\text { Complex A } \\
\text { ( } 3 \text { small. } \\
\text { adjacent } \\
\text { shel ters) }\end{array}$ & $850^{\prime}$ & See text. & $\begin{array}{l}\text { Mud Creek } \\
\text { (now dry) }\end{array}$ & 5 & $0-2$ & $\begin{array}{l}\text { A light to moder- } \\
\text { ate scattering of } \\
\text { lithic debris in } \\
\text { each of the } 3 \\
\text { shelters and a } \\
\text { concentrated } \\
\text { area of workshop } \\
\text { activity in } \\
\text { sheiter A-3. }\end{array}$ & $\begin{array}{l}\text { Al though the complex } \\
\text { is only lightly dis- } \\
\text { turbed, frequency of } \\
\text { archaeological arti- } \\
\text { facts is jight. The } \\
\text { only area of poten- } \\
\text { tial, shelter A-3, } \\
\text { was extensive?y } \\
\text { tested. }\end{array}$ & No further work. & \\
\hline $10-3$ & $\begin{array}{l}\text { Rockshel ter } \\
\text { Complex B } \\
\text { (2 adjacent } \\
\text { shelters) }\end{array}$ & $840^{\prime}$ & See text. & $\begin{array}{l}\text { Mud Creek } \\
\text { (now dry) }\end{array}$ & $3-4$ & $2-3$ & $\begin{array}{l}\text { Shelters B-l and } \\
\text { B-2 show a very } \\
1 \text { ight activity } \\
\text { area; the exca- } \\
\text { vations on talus } \\
\text { slope of B-2 re- } \\
\text { vealed a heavy } \\
\text { concentration of } \\
\text { biface fragments, } \\
\text { primary, secon- } \\
\text { dary and tertiary } \\
\text { flakes. }\end{array}$ & $\begin{array}{l}\text { The depth and fre- } \\
\text { quency of arti- } \\
\text { facts recovered } \\
\text { from a limited area } \\
\text { on the talus of } B-2 \\
\text { warrant further } \\
\text { excavation in and } \\
\text { around shelter } B-2 \\
\text { to further deter- } \\
\text { mine the signifi- } \\
\text { cance of the } \\
\text { deposits. }\end{array}$ & $\begin{array}{l}50-\mathrm{cm}^{2} \text { and } 1-\mathrm{m}^{2} \\
\text { test pits in } \\
\text { and around } \\
\text { Rockshelter } \mathrm{B}-2 \text {. }\end{array}$ & $\begin{array}{l}\text { Total erea } \\
\text { required for } \\
\text { complete exca- } \\
\text { vation and/or } \\
\text { intensive test- } \\
\text { ing of the } \\
4 \times 6 \text { m shelter } \\
\text { is limited. }\end{array}$ \\
\hline $15-3$ & $\begin{array}{l}\text { Terrace, } \\
\text { workshop } \\
\text { site }\end{array}$ & $760-775^{\circ}$ & $375 \times 250$ & $\begin{array}{l}\text { Mud Creek } \\
\text { (nowt dry) }\end{array}$ & $3-4$ & $0 m-250$ & $\begin{array}{l}\text { Extensive scatter } \\
\text { of lithic debris } \\
\text { in wide area. }\end{array}$ & $\begin{array}{l}\text { A scattering of } \\
\text { burned rocks was } \\
\text { observed eroding } \\
\text { from a concentrated } \\
\text { area and lithic } \\
\text { debris in the Nh } \\
\text { sector. }\end{array}$ & $\begin{array}{l}\text { Limited test- } \\
\text { ing and exca- } \\
\text { yation to } \\
\text { determine depth } \\
\text { and extent. }\end{array}$ & \\
\hline
\end{tabular}

* Beyond the jurisdiction of the 5CS. See Sumary and Recormendations. 


\section{REFERENCES CITED}

Blair, W. F.

1950 The Biotic Provinces of Texas. Texas Journal of Science 2(1):93-116.

Brown, D., P. Lukowski, T. R. Hester and J. Eaton

1977 Archaeological Assessment of Two Sites in the Vicinity of Floodwater Retarding Structure No. 11, Salado Creek Watershed, Bexar County, Texas. Center for Archaeological Research. The University of Texas at San Antonio, Archaeological Survey Report 35.

Carr, J. T., Jr.

1969 The Climate and Phys fography of Texas. Texas Water Development Board, Repart 53.

Epstein, J. F.

1969 The San Isidro Site: An Early Man Campsite in Nuevo Leon, Mexico. Department of Anthropology. The University of Texas at Austin, Anthropology Series 7.

Fawcett, W. B., Jr.

1972 The Prehistory of Bexar County: A Study of Previous Work in South Central Texas. Bulletin, Lower Plains Archaeological Society 2 (for 1971).

Fox, A. A.

1977 An Archaeological Assessment of the San Antonio 201 Wastewater Treatment Project. Center for Archaeological Research, The University of Texas at San Antonio, Archaeological Survey Report 41.

Gerstle, A., T. C. Kelly and C. Assad

1978 The Fort Sam Houston Project: An Archaeological and Historical Assessment. Center for Archaeological Research, The University of Texas at San Antonio, Archaeological Survey Report 40.

Hester, T. R.

1975 Archaeological and Historical Resources in the San Antonio-Guadalupe River Basins: A Preliminary Statement. Center for Archaeological Research, The University of Texas at San Antonio, Regional Studies 1. 
1976 The Archaic of Southern Texas. In: The Texas Archaic: A Symposium (T. R. Hester, ed.). Center for Archaeological Rescarch, The University of Texas at San Antonio, Special Report 2:83-88.

1978 Early Human Occupation in South Central and Southwestern Texas: Preliminary Papers on the Baker Cave and S. Mary's Hall Sites. Center for Archaeological Research, The University of Texas at San Antonio.

Hester, T. R. and H. Kohnitz

1975 The Chronological Placement of Guadalupe Tools. La Tierra 2(2):22-25.

Hester, T. R., R. F. Heizer and J. A. Graham

1975 Field Methods in Archaeology, 6th Edition. Mayfield Publishing Company, Palo Alto, California.

Hester, T. R., F. A. Bass and T. C. Kelly

1975 Archaeological Survey of Portions of the Comal River Watershed, Comal County, Texas. Center for Archaeological Research. The university of Texas at San Antonio, Archaeological Survey Report 6.

Hester, T. R., F. A. Bass, Jr., A. A. Fox, T. C. Kelly, M. F. Chadderdon and E. S. Harris

1974 Archaeological Survey of Areas Proposed for Modification in the Salado Creek Watershed, Bexar County, Texas. Center for Archaeological Research. The University of Texas at San Antonio, Archaeological Survey Report 3.

Hudson, W. R., Jr., W. M. Lynn and D. Scurlock

1974 Walker Ranch, An Archaeological Reconnaissance and Excavations in Northern Bexar County, Texas. Texas Historical Commission, Report 26.

Jaquier, J. A., T. R. Hester, F. Valdez, Jr., A. J. McGraw and I. W. Cox

1978 Archaeological Test Excavations at Site 41 BX 228, Walker Ranch, Bexar County, Texas. Center for Archaeological Research. The University of Texas at San Antonio, Archaeological Survey Report 46.

McGraw, A., F. Valdez, Jr. and W. Cox

1977 An Archaeological Survey of Areas Proposed for Modification in the Encino Park Development, Northern Bexar County, Texas. Center for Archaeological Research. The University of Texas at San Antonio, Archaeological Survey Report 39. 
McGraw, A. J. and F. Valdez, Jr.

1977 A Preliminary Assessment of Archaeological Resources at Tobins 0akwell Farm, San Antonio, Texas. Center for Archacological. Research. The University of Texas at San Antonio, Archaeological Survey Report 43.

Redman, C. L.

1974 Archaeological Sampling Strategies. Addison-Wesley Modules in Anthropology 55.

Schuetz, M. K.

1966 The Granberg Site: An Archaic Indian Habitation in Bexar County, Texas. Witte Museum Studies 1. San Antonio.

Scurlock, D. and W. R. Hudson

1973 An Archaeological Investigation of walker Ranch. Texas Historical Commission, Austin.

Sollberger, J. B. and T. R. Hester

1972 The Strohacker Site: A Review of Pre-Archaic Manifestations in Texas. Plains Anthropologist $17(58): 326-344$.

Smith, H. P., Jr., and K. McDonald

1975 An Archaeological Survey of Friedrich Park, Bexar County, Texas. Center for Archaeological Research. The University of Texas at San Antonio, Archaeological Survey Report 12.

Taylor, F. B., R. B. Hailey and D. L. Richmond

1966 Soil Survey of Bexar County, Texas. U. S. Department of Agriculture, Soil Conservation Service, Series 1962. 